\title{
Fragmentation and the Temne: From War Raids into Ethnic Civil Wars
}

\author{
The Temne and Their Neighbours: A Long-Standing Scenario of \\ Inter-ethnic Hostilities?
}

The former British colony of Sierra Leone is today regarded as one of the classic cases of a society that is politically polarised by ethnic antagonism. By the 1950s, the decade before independence, ethnic fault lines had an impact on local political life and the inhabitants of the colony appeared to practise ethnic voting. Both the Sierra Leone People's Party (SLPP) government formed after 1957, led by Milton Margai, and the All People's Congress (APC) government of Siaka Stevens coming to power in $1967 / 68$, relied on ethnic support and created ethnic networks: the SLPP appeared to be 'southern' and 'eastern', and Mende-dominated, the APC 'northern' and Temne-led. ${ }^{1}$ Between 1961 and the 1990s, such voting behaviour can be found in sociological and political science survey data. ${ }^{2}$ However, the period of brutal civil war in the 1990 s weakened some of these community links, as local communities were more interested in their survival than in ethnic solidarities. ${ }^{3}$ We have seen that the 2007 legislative elections contradicted this apparent trend.

Before the second half of the nineteenth century, the territory of present-day Sierra Leone was politically fragmented into a number of different small structures, which were often much smaller than the pre-colonial states of Senegambia (Map 4). The only regional exception was the 'federation' of Morea, which, however, was an unstable entity. The slave trade and the 'legitimate commerce' in palm

1 Cartwright, John R., Politics in Sierra Leone 1947-67 (Toronto - Buffalo: University of Toronto Press, 1970), 101-2, 128; Fisher, 'Elections', 621-3; Riddell, J. Barry, 'Beyond the Geography of Modernization: The State as a Redistributive Mechanism in Independent Sierra Leone', Canadian Journal of African Studies 19(3), 1985, 529-45, 532; Kandeh, Jimmy D., 'Politicization of Ethnic Identities in Sierra Leone', African Studies Review 35(1), 1992, 81-99, 93-4.

2 Kandeh, 'Politicization', 97; Hayward, Fred M., and Ahmed R. Dumbuya, 'Changing Electoral Patterns in Sierra Leone: The 1982 Single-Party Elections', African Studies Review 28(4), 1985, 62-86, 66-7; Riddell, J. Barry, 'Internal and External Forces Acting upon Disparities in Sierra Leone', Journal of Modern African Studies 23(3), 1985, 389-406, 402-4.

3 Hirsch, John L., Sierra Leone: Diamonds and the Struggle for Democracy (Boulder - London: Lynne Rienner, 2001), 52-4. 


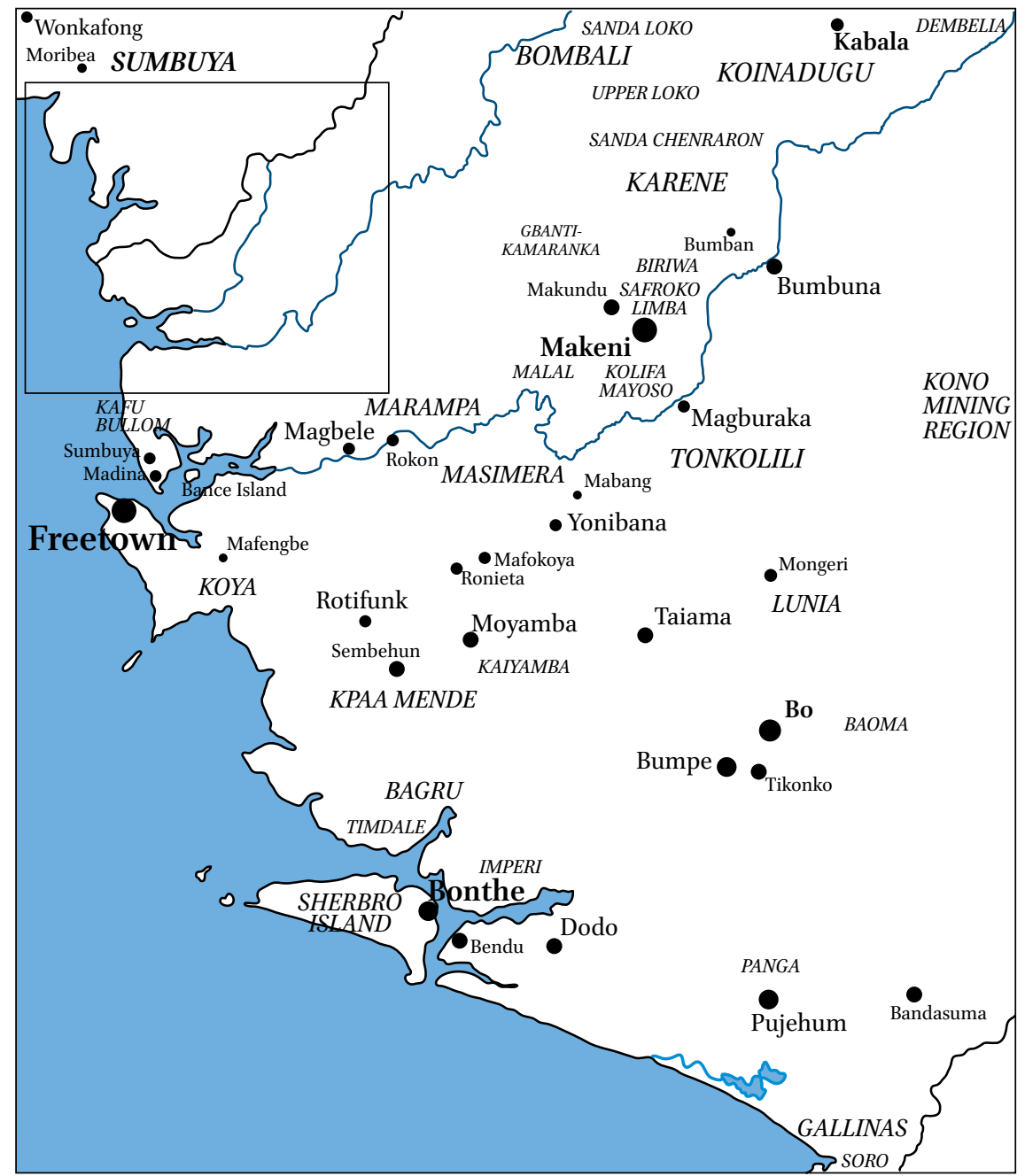

MAP 4

Sierra Leone

products in the nineteenth century did notlead to political centralisation. The region also knew little linguistic coherence; in the early nineteenth century, European missionaries complained that it made little sense to learn Temne as it was not a lingua franca among the northern languages. ${ }^{4}$ The fragmentation may explain

4 Archives of the Church Missionary Society, University of Birmingham Library, Birmingham (CMS), C A1/E5A - 95, Gustav Nylander, CMs missionary, to Pratt, Secretary of the Church Missionary Society (without number), 19 Dec. 1816, 2; CMS, C A1/E6 - 42, Nylander, Statement of Yongroo Somoh (without number), 25 March 1817, 2. 


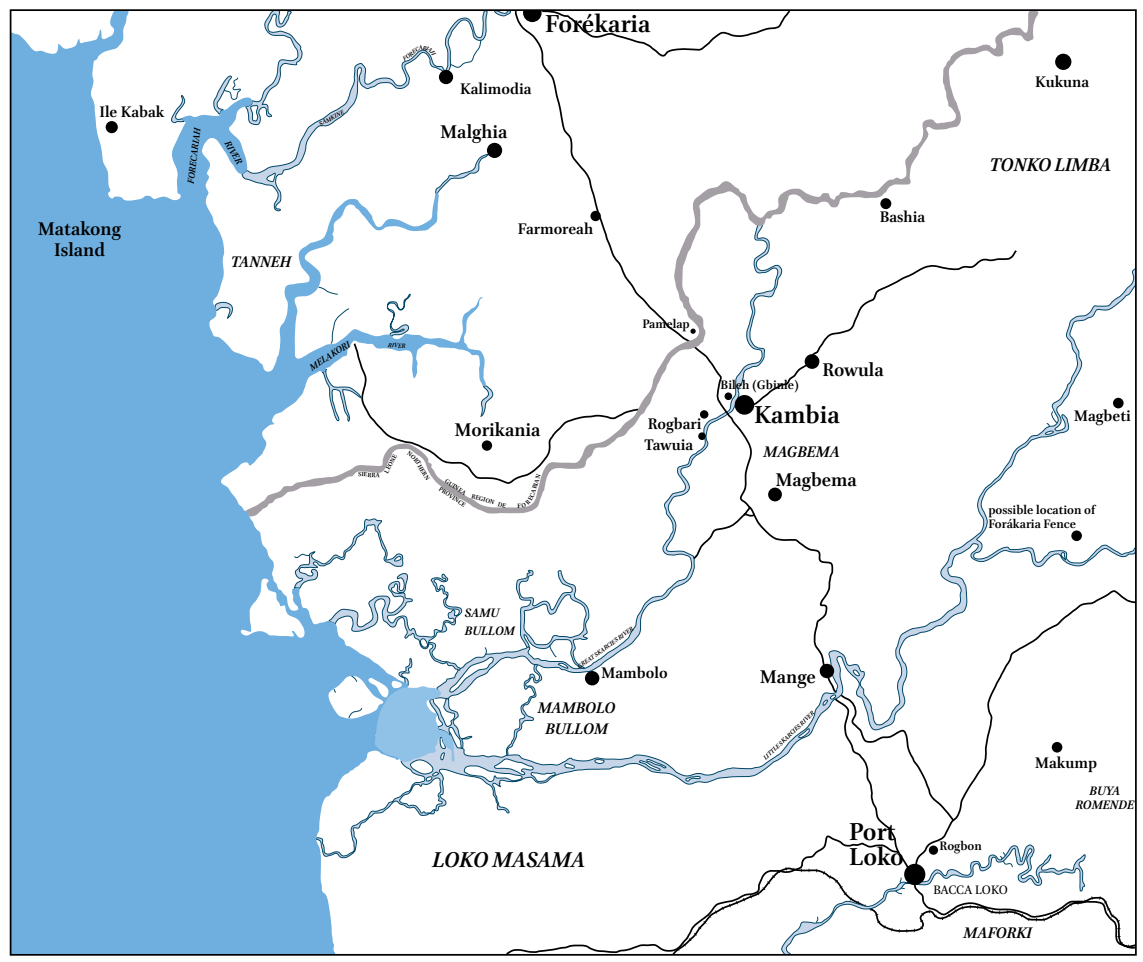

MAP $5 \quad$ Northern Sierra Leone and Southern Guinea border regions

the absence of more detailed studies, as 'Temne' settlements such as Port Loko, Magbele, and Rokon, or rural political units such as Marampa, Koya, and Masimera, but also their non-Temne-speaking neighbours such as Morekania, Kalimodia, or Malghia, had only some thousand inhabitants each (Map 5). None of these small entities was a pre-colonial state in a larger sense. ${ }^{5}$

In contrast, once Sierra Leone had become independent, ethnicity as a category was everywhere. The census of 1963 gave detailed statistics about 'tribal groups': from an estimate of 2.18 million inhabitants in the country, $30.9 \%$ were classified as Mende, and $29.8 \%$ as Temne; among the smaller ethnic communities, 8.4\% were Limba, 3.1\% Susu, 3\% Loko, 2.3\% Mandinka, 2.2\% 'Kissi',

5 Fyfe, Christopher, A History of Sierra Leone (Oxford: Oxford University Press, 1962); Wylie, Kenneth C., The Political Kingdoms of the Temne: Temne Government in Sierra Leone 1825-1910 (New York: Africana Publications, 1977), 92; Caulker, Patrick S., 'Legitimate Commerce and Statecraft: A Study of the Hinterland Adjacent to Nineteenth-Century Sierra Leone', Journal of Black Studies 11(4), 1981, 397-419, 399-400, 413-5. 
and $1.9 \%$ Creole. $^{6}$ Anthropological research from the colonial period, which had established stereotypes of dressing and walking styles of members of the different ethnic groups, also emphasised 'tribal histories' of migration. ${ }^{7}$ Those were subsequently transformed into 'official' narratives of the pre-colonial past. $^{8}$ As Christopher Fyfe and Vernon Dorjahn have pointed out, this perspective overstated the idea of patterns of group migration.

In the colonial period, generalisations were more complicated, in spite of administrators' wishes to establish clear categories. ${ }^{9}$ In colonial census data, 'the Mende' and 'the Temne', as the large ethnic communities are categorised, are very unstable in size. Changes in ethnic identification, as reported in interviews, are enormous. Thus, in his Annual Report for 1922, the governor of Sierra Leone, Raymond Slater, claimed that 'the Mendes are far more numerous than the other tribes'. ${ }^{10}$ Only one year later, the picture drawn by the same census officials was entirely different: there were suddenly many more 'Temne', and the administration reported near-parity between the two groups."

Also, British administrators slowly learned that linguistic unity did not necessarily mean cultural homogeneity: differences in family organisation between the Temne of the different regions of Karene, Bombali, Port Loko, and Koinadugu were remarkable. ${ }^{12}$ Even so, a stereotype of Temne-ness survived

Devis, T.L.F., 'Fertility Differentials among the Tribal Groups of Sierra Leone', Population Studies 27(3), 1973, 501-14, 508, 513.

7 Little, Kenneth L., The Mende of Sierra Leone: A West African People in Transition (second edition, London: Routledge \& Kegan Paul, 1967 [1951]), 70-1; Clarke, Robert, 'Sketches of the Colony of Sierra Leone and Its Inhabitants', Transactions of the Ethnological Society of London 2, 1863, 320-63, 325-7, 350-63.

8 Kup, Peter Alexander, 'An Account of the Tribal Distribution of Sierra Leone', Man 6o, 1960, 116-9, passim. The idea of massive migration into the coastal area has been questioned in Jones, Adam, 'Who were the Vai?', Journal of African History 22(1), 1981, 159-78, 175-8; Dorjahn, Vernon R., and Christopher Fyfe, 'Landlord and Stranger: Change in Tenancy Relations in Sierra Leone', Journal of African History 3(3), 1962, 391-7, 393.

9 Renner, G.T., 'Geographic Regions of Sierra Leone', Economic Geography 7(1), 1931, 41-9, $44-6$.

$10 \quad$ TNA, PRo, CO/267/599, Slater, Governor of Sierra Leone, Sierra Leone: Annual General Report for 1922 (without number), without date.

11 TNA, PRO, CO/267/603, Sierra Leone: Annual General Report for 1923 (without number), without date, 2.

12 TNA, PRo, CO/267/595, Stanley, Provincial Commissioner of the Northern Province, [Report on the Northern Province] (without number), 12 April 1922, 2; Oyètádé, B. Akíntúndé, and Victor Fashole Luke, 'Sierra Leone: Krio and the Quest for National Integration', in Andrew Simpson (ed.), Language \& National Identity in Africa (Oxford etc.: Oxford University Press, 2008), 122-40, 126. 
into the post-colonial state. Moreover, in public discourse, Temne-speakers poured scorn upon the 'savage', and 'generally backward and unclean', Limba - a neighbouring group living in the north-eastern interior of Sierra Leone. They characterised the Mende-speakers as plunderers and marauders. Regarding the Loko, who mostly settled in close proximity to or jointly with Temne-speakers, the discourse was also unfriendly, and 'Loko' equated with potential slave. ${ }^{13}$

As in the case of the Wolof of Senegambia, interaction with neighbouring groups was also essential for the Temne of Sierra Leone, both in the late precolonial and colonial periods. It is thus necessary to elaborate briefly on these communities. Like Temne-speakers in the north, the Mende-speakers were organised in rather small local communities without much centralisation, although the presence of female rulers constituted a difference. ${ }^{14}$ Settlements like Panguma, Bumpe, Mongeri, and Tikonko played a role in the political stabilisation of the region and regional commerce. ${ }^{15}$ Apart from that, Mende-speakers were particularly proud of their reputation as fearsome warriors, and they appeared as mercenaries in several of the conflicts in northern Sierra Leone. From the 1880s, British visitors called a certain region 'Mendi-Land', a label exclusively based on language, as early missionaries in the coastal Sherbro had not even heard of the category of 'Mende. ${ }^{16}$ Early anthropological reports also point to a certain 'fragmentation' of Mende identifications: in the 1940s, Mendespeakers in eastern Sierra Leone pointed to the inhabitants of the region of Kpaa Mende, the most renowned source of mercenaries, as being 'not really Mende' or

13 Dorjahn, Vernon R., 'Migration in central Sierra Leone: the Temne chiefdom of Kolifa Mayoso', Africa 45(1), 1975, 29-49, 45-6. Temne-speakers did sometimes consider the 'Limba' as part of the 'Mandinka' of the north, see TNA, PRo, CO/879/17, African Confidential Print No. 206, Lawson, Secretary of Native Affairs in Freetown, to Rowe, Governor of Sierra Leone (without number, Enclosure No. 1), without date; TNA, PRO, CO/879/15, African Confidential Print No. 173, Rowe to Hicks Beach, British Secretary of State for the Colonies $\left(\mathrm{n}^{\circ} 200\right.$, in series as No. 11$), 18$ Dec. $1878,2$.

14 Jambai, Amara, and Carol MacCormack, 'Maternal Health, War, and Religious Tradition: Authoritative Knowledge in Pujehun District, Sierra Leone', Medical Anthropology Quarterly, New Series 10(2), 1996, 270-86, 279; Nyerges, A. Endre, 'Ethnography in the Reconstruction of African Land Use Histories: A Sierra Leone Example', Africa (London) 66(1), 1996, 122-44; Day, Linda, 'Nyarroh of Bandasuma, 1885-1914: A Reinterpretation of Female Chieftaincy in Sierra Leone', Journal of African History 48(3), 2007, 415-37, 416-7, $435^{-6 .}$

15 Little, Mende, 29; Alldridge, T.J., 'Wanderings in the Hinterland of Sierra Leone', Geographical Journal 4(2), 1894, 123-40, 126.

16 CMS, C A1/E7A - 52, Cates, CMs missionary, to Pratt (without number), 19 April 1819, 1-2. 
'half-Temne'. Even in the 1950s, the solidarities among Mende-speakers often concentrated on the local community. Mende-speakers had their own Poro secret societies, but those were not particularly linked to ethnic sentiment. ${ }^{17}$ Only with the establishment of the SLPP regime in the late 1950s is it possible to speak of a 'Mende solidarity', expressed in common voting behaviour.

The Limba-speakers in northern Sierra Leone were regarded, by many Sierra Leoneans, as a community of 'deep autochthons' - who lived in the country before all the other immigrants - and were both peaceful peasants and occasional plunderers of caravans. ${ }^{18}$ Scholarly research tends to characterise this group in a simplified manner, as particularly homogeneous. However, during the nineteenth century, the Limba-speaking ruler, Almami Amadu Suluku, formed a small pre-colonial state in Biriwa ruling over a diverse group of inhabitants with a variety of languages. ${ }^{19}$ Group solidarity among the Limba was not automatic, and they had no exclusive political entity.

Communities of speakers from the Mande linguistic group have certainly been privileged by scholarly attention. This is particularly so for the Dyula family networks active in regional commerce in the river system, including Forékaria, Melikori, and the Skarcies Rivers. Dyula families also established political power and Islamic influence in some cases, and Dala Modu Dumbuya, a Dyula merchant and leader of warriors from the city of Wonkafong between 1801 and 1841, was instrumental in this process. ${ }^{20}$ However, these conversion processes were sometimes slow and we have to avoid over-simplification: even the town centre of Wonkafong only became a Muslim settlement around 1880, and other communities only converted under colonial rule later in the

17 However, it is true that several expressions describing Mende Poro have been imported into the Temne language, see Turay, A.K., 'Language contact: Mende and Temne - a case study', Africana Marburgensia 11(1), 1978, 55-73, 56-7.

18 Fanthorpe, Richard, 'Limba “Deep Rural” Strategies', Journal of African History 39(1), 1998, $15-38,17-9$.

19 Fyle, C. Magbaily, Almamy Suluku of Sierra Leone c. 1820-1906: The Dynamics of Political Leadership in Pre-Colonial Sierra Leone (London - Ibadan: Evans Brothers Ltd., 1979), 4-6, 12-3; Finnegan, Ruth, 'How to Do Things with Words: Performative Utterances Among the Limba of Sierra Leone', Man, New Series 4(4), 1969, 537-52, 542-4. TNA, PRO, CO/270/8, Reverend J. Bright, Journal of Mr. Bright's Expedition to the Mandingo Country performed in Sept. ${ }^{r}$ and Oct. ${ }^{r} 1802$ (without number), 50-1; CMS, C A1/E1 - 57, Hartwig, CMS missionary, to Pratt (without number), 10 May 1806; Skinner, David E., 'Islam and Education in the Colony and Hinterland of Sierra Leone (1750-1914)', Canadian Journal of African Studies 10(3), 1976, 499-520, 501; Skinner, David E., 'Mande Settlement and the Development of Islamic Institutions in Sierra Leone', International Journal of African Historical Studies 11(1), 1978, 32-62, 35-7, 47. 
twentieth century. ${ }^{21}$ Although we do find cultural transfer, as Temne-speaking rulers took part of their titles and government terminology, but also ideas of social stratification, from Mande models, Temne Islam remained integrated in local cults and Poro practices. ${ }^{22}$ Moreover, even with gradual Islamisation amongst the Temne-speakers, the role of Muslim preachers was strongly identified with a 'Mandinka ethnicity'. ${ }^{23}$ But itinerant preachers ultimately made considerable progress in the northern part of the Protectorate, and the Temnespeaking regions of late colonial and post-colonial Sierra Leone therefore became predominantly Muslim. ${ }^{24}$

From their first encounters with European diplomats and representatives, Susu, Yalunka, Mandinka, and Koranko spokesmen had periodically insisted on being part of a larger 'Mandingo group'. ${ }^{25}$ In northern Sierra Leone, 'Mandinka' and 'Susu' appear as the adversaries of the Temnespeaking populations for much of the nineteenth century. Susu-speaking war leaders exerted strong pressure on Temne communities and conquered important settlements inhabited by large groups of Temne-speakers, like Port Loko and Kambia. Then, in the twentieth century, both the Susu and the Mandinka found themselves cut off from the political life of Sierra Leone by the colonial border between this colony and the French territory of Guinea-Conakry.

Urban experiences through migration from an early date brought Temnespeaking individuals into contact with other groups from more distant regions. The larger town centres of the Temne-speaking zones - such as Kambia, Port Loko, Rokel, or Magbele - were too close to the Sierra Leone Peninsula and, in

21 TNA, PRO, CO/879/18, African Confidential Print No. 226, Simineh Simba, Translation of a letter written in Arabic addressed to his Excellency the Administrator-in-Chief, from King Simminee Simba, of the Soombuyah Country. (without number), 3 Dec. 188o, 1.

22 Anwyl, T.C., 'The Timne and Other Tribes of Sierra Leone', Journal of the Royal African Society 16(61), 1916, 36-51, 38-40; Wylie, Kenneth, 'The Influence of the Mande on Temne Political Institutions: Aspects of Political Acculturation', International Journal of African Historical Studies 7(2), 1974, 255-71, 261, 265.

23 Alldridge, T.J., 'Wanderings', $136-7$.

24 Yambasu, Sahr J., 'Order and Disorder: the Mende and Missionary Case', Paideuma 39, 1993, 111-34, 115-9.

25 TNA, PRo, CO/267/595, Stanley, [Report on the Northern Province] (without number), 12 April 1922, 2; Jackson, Michael, The Kuranko: Dimensions of Social Reality in a West African Society (London: Hurst, 1977), 1-4; Bah, M. Alpha, Fulbe Presence in Sierra Leone: A Case of Twentieth-Century Migration and Settlement among the Kissi of Koindu (New York etc.: Peter Lang, 1988), 44-6. 
the nineteenth century, uninteresting as an alternative for immigration. ${ }^{26}$ Therefore, migrants concentrated in Freetown. In the urban settlement under British rule, alliances between different inhabitants were possible, for example against Lebanese merchants who became victims of violent mobs. ${ }^{27}$ Even so, as in Senegambia, urban settings could also strengthen an ethnic solidarity based on professional identification, as for the Kru community from the south, who specialised in navigation and piloting.

Temne-speaking regions were politically unstable, partly because of their participation in the slave trade and the creation of slave villages that occasionally turned against the Temne rulers. Instability expressed itself in widespread plundering campaigns, comparable again to Senegambia. Localised wars thus dominated much of the nineteenth century. ${ }^{28}$

In the next sections of this chapter, I will analyse the evolution of solidarities between different Temne-speaking groups north of Freetown when faced with the colonial presence. As we have seen, the Temne case is one where any stronger pre-colonial state structures were notably absent - and thus an important example. The methodological approach to the discussion of precolonial Temne identifications will be slightly different to that of the cases of the Wolof and the Ewe. The documentation relevant to a study on the Temne still mainly comes from British archives, although additional analyses have been carried out at the Sierra Leone National Archives.

In the early nineteenth century, British residents in Sierra Leonean territory were much more active than the French in Senegal. The colony of Freetown and its population of 'liberated slaves' played the crucial role in this respect, as they treated the 'Temne' regions as the 'hinterland' of this settler colony. ${ }^{29}$

26 Riddell, J. Barry, and Milton E. Harvey, 'The Urban System in the Migration Process: An Evaluation of Step-Wise Migration in Sierra Leone', Economic Geography 48(3), 1972, $270-83,279$.

27 Abdullah, 'Rethinking', 210-1.

28 Rashid, Ismail, 'Escape, Revolt and Marronage in 18th and 19th century Sierra Leone', Canadian Journal of African Studies 34(3), 2000, 656-83, 664-8; Mouser, Bruce L., 'Rebellion, Marronage and Jihād: Strategies of Resistance to Slavery on the Sierra Leone Coast, c. 1783-1796', Journal of African History 48(1), 2007, 27-44, 38; Mouser, Bruce L., 'Trade, Coasters, and Conflict in the Rio Pongo from 1790 to 1808', Journal of African History 14(3), 1973, 45-64, 56-8.

29 Sibanda, M.J.M., 'Dependency and Underdevelopment in Northwestern Sierra Leone, 1896-1939', African Affairs 78(313), 1979, 481-92, 481; Wyse, Akintola J.G., 'The Sierra Leone Branch of the National Congress of British West Africa, 1918-1946', International Journal of African Historical Studies 18(4), 1985, 675-98, 684; Eluwa, G.I.C., 'Background to the 
The liberated slaves or 'Creoles' residing in the settlement represented just as much of a crucial factor in the process as white administrators. ${ }^{30}$

The Temne-speakers living close to the Freetown peninsula initially attempted to destroy the settlement, and the 1790s and early 1800 s were characterised by regional wars. ${ }^{31}$ The British administration therefore depended upon comparatively good information about its neighbours, and detailed reports on group identifications already existing in the nineteenth century. The British also set up networks, which had the function of opening trade routes and facilitating contacts with different communities. Through these activities, British residents rapidly knew that the region lacked stronger precolonial state structures, except the Almaminate (or 'federation') of Morea some fifty kilometres to the north, which appeared as a composition of many different communities. ${ }^{32}$ In the political networks of this region, Susu- and Mandinka-speakers were the more prominent among the rulers, but several local leaders spoke Temne, Bullom, Sherbro or Loko as their first language. It is also questionable, in the context of the early nineteenth century, to speak of a Mande-Dyula 'nationalism'. The British would have wished to classify local populations into clear-cut 'tribal' groups, such as 'Mandingo' and 'Soosoo', but in most cases of local warfare, the smaller political units were the decisive

Emergence of the National Congress of British West Africa', African Studies Review 14(2), 1971, 205-18, 206-8.

30 Goerg, Odile, 'From Hill Station (Freetown) to Downtown Conakry (First Ward): Comparing French and British Approaches to Segregation in Colonial Cities at the Beginning of the Twentieth Century', Canadian Journal of African Studies 32(1), 1998, 1-31, 11-2; CMS, C A1/O 83/1, John Henry Davies, CMS native catechist, [Report from Magbele 1857] (without number), without date [1857], 1, 10-1.

31 Deveneaux, Gustav, 'The turbulent frontier: aspects of relations between the colony of Sierra Leone and Koya, 1787-189o', Africana Research Bulletin (Fourah Bay, Sierra Leone) 15, 1981, 81-125, 90.

In 1879, the Almami Bokari of Morea claimed that the Bullom and the Digsing Temne the northernmost Temne-speaking group - had been subjects of the rulers of the federation for over 200 years already! This might be exaggerated, but at least it shows the conception of the Federation of Morea as a 'multi-ethnic entity', see TNA, PRO, CO/879/17, African Confidential Print No. 206, Statement of accredited Messenger from Alimamy Bocarry with reference to the Island of Matacong (without number, Sub-Enclosure No. 5.), 18 July 1879, 2; Mouser, Bruce L., 'Continuing British Interest in Coastal Guinea-Conakry and the Fuuta Jaloo Highlands (1750 to 1850)', Cahiers d'Etudes Africaines 43(172), 2003, 761-90, 771-3; Howard, Allen M., 'The Relevance of Spatial Analysis for African Economic History: The Sierra Leone-Guinea System', Journal of African History 17(3), 1976, 365-88, 370-2; McGowan, Winston, 'The Establishment of Long-Distance Trade between Sierra Leone and Its Hinterland, 1787-1821', Journal of African History 31(1), 1990, 25-41, 30-2. 
point of reference. ${ }^{33}$ Timbo in the Fuuta Jallon constituted perhaps the most notable exception to this pattern. While coastal communities with Muslim rulers accepted for part of the nineteenth century the religious overlordship of the Almami to whom they gave the honorary title of abbas, they nevertheless referred to the inhabitants of the Fuuta Jallon as 'Fula plunderers'. However, this was probably by far the strongest ethnic line drawn in the region, and its effects were exceptional. ${ }^{34}$

British activities against the slave trade intensified European contact with groups in the region, as it was part of the anti-slavery strategy to convince local rulers of the advantages of alternative forms of production and to open new trade routes. Ironically, the new restrictions on the slave trade led to more brutal practices of enslavement and to the imprisonment of a large number of victims concentrated in one place. They also provoked more violent wars. ${ }^{35}$ This again drew the British more closely into the political developments of the broader region beyond the Freetown Peninsula, and led to more interaction with Temnespeakers. Much of this interaction was initially carried out by 'Creole' officials working for the colonial government, who introduced their own opinions into the discussion and generally regarded local populations as 'primitive'. In the second half of the nineteenth century, Creoles like J.C.E. Parkes and Thomas George Lawson held the post of Secretary of Native Affairs of the Sierra Leone

33 Mouser, Bruce L., 'The 1805 Forékariah Conference: A Case of Political Intrigue, Economic Advantage, Network Building, History in Africa 25, 1998, 219-62; CMS, C A1/E1 - 57, Hartwig, cMS Missionary at Wonkafong, to Pratt, CMS Secretary (without number), 10 May 1806, 1; CMs, C A1/E3 - 39, Renner, CMs Missionary at Bashia, to Pratt (without number), 24 Dec. 1812, 1-4; Keese, Alexander, 'Who's King Tom? Being a "Temne", "Mandinka", or "Susu" between identity, solidarity and ethnic shifts in early nineteenthcentury Sierra Leone', in Alexander Keese (ed.), Ethnicity and the long-term perspective: the African Experience (Berne etc.: Peter Lang, 2010), 191-211, 206-8.

34 TNA, PRO, CO/267/149, Campbell, Governor of Sierra Leone, to Glenelg, British Secretary of State for War and the Colonies (without number), 19 May 1838, 19.

Bethell, Leslie, 'The mixed commission for the suppression of the Trans-Atlantic slave trade in the nineteenth century', Journal of African History $7(1$ ), 1966, 79-93, 80-82; Turano, Maria, 'La commission mixte luso-britannique à Boa Vista et le procès du bateau "Leão"', in Centro de Estudos Africanos da Universidade do Porto (ed.), Trabalho forçado africano - articulações com o poder político (Porto: Campo de Letras, 2007), 117-34, 117-8; Howard, Allen M., 'Nineteenth-Century Coastal Slave Trading and the British Abolition Campaign in Sierra Leone', Slavery \& Abolition 27(1), 2006, 23-49, 32; Wylie, Kingdoms, 62; Siddle, S.D., 'War-Towns in Sierra Leone: A Study in Social Change', Africa (London) 38(1), 1968, $47-56$. 
Colony and strongly influenced the colonial view on local communities. ${ }^{36}$ Even so, before the 1870 s, much of the contact with the Temne was still based on a foundation of diplomatic exchange rather than domination.

The creation of the Protectorate in Sierra Leone in 1898 changed the political scenery. Firstly, within the organisation of the colonial presence at the end of the nineteenth century, it is possible to speak of the end of Creole influence in the colonial administration. A new racist tendency undermined the role of the 'Creoles', although it was somewhat mitigated by the lobbying of 'Creole intellectuals' and Christian networks. ${ }^{37}$ Even so, in the interwar period, the Freetown Creoles reappeared as leaders of political movements and as activists in strikes and social protests, which partly spilled over into the Protectorate. ${ }^{38}$ Secondly, the creation of the Protectorate entrenched the position of important paramount chiefs. However, Creole politicians quickly learned how to use bodies like the Legislative Council to their benefit. In terms of flows of information and discussion about identifications, information was now more consistently transmitted by immigrants to Freetown coming from the Protectorate. Moreover, sons of 'native chiefs' enjoyed education in Fourah Bay (now part of Freetown), in Bo, and other college institutions, which guaranteed the link between the urban centres and the rural constituencies. ${ }^{39}$

Between the Second World War and the independence of Sierra Leone in 1961, the dominant position of Creoles in emergent politics was undermined. Administrators, who feared Communist infiltration in the colony, were particularly negative about the Creole 'educated natives' of Freetown, such as party leader Isaac T.A. Wallace-Johnson. ${ }^{40}$ The removal of the boundary between 'Colony' and 'Protectorate' was a means to neutralise Creole influence. The Freetown elites attempted nevertheless to broaden their support base in the

36 Hargreaves, John D., 'The Establishment of the Sierra Leone Protectorate and the Insurrection of 1898', Cambridge Historical Journal 12(1), 1956, 56-80, 58; Howard, 'Trading', 38; Skinner, David E., Thomas George Lawson: African Historian and Administrator in Sierra Leone (Stanford: Hoover Institution Press, 1980), 43-9.

37 Goerg, Odile, 'Between Everyday Life and Exception: Celebrating Pope Hennessy Day in Freetown, 1872-c. 1905, Journal of African Cultural Studies 15(1), 2002, 119-31, 123; Fyfe, Christopher, and David Killingray, 'A Memorable Gathering of Sierra Leonians in London, 1919', African Affairs 88(350), 1989, 41-6, 44-5; Hair, P.E.H., 'Africanism: The Freetown Contribution', Journal of Modern African Studies 5(4), 1967, 521-39, 533.

38 Goerg, Odile, 'Sierra Leonais, Créoles, Krio: La Dialectique de l'Identité', Africa 65(1), 1995, 114-32, 117-9.

39 Wyse, Akintola J.G., The Krio of Sierra Leone (London: Hurst, 1989), 105-11.

40 Spitzer, Leo, and LaRay Denzer, 'I.T.A. Wallace-Johnson and the West African Youth League', International Journal of African Historical Studies 6(3), 1973, 413-52, 422. 
$195^{1}$ and 1957 elections. The Creole-dominated United Progressive Party (UPP) showed some successful resistance against the progress of the SLPP, a party with rural support bases, and won a number of Protectorate seats in the elections. However, with the help of the British administration, Milton Margai's party in the end began to dominate the institutions in the territory. ${ }^{41}$ This led to a retreat of the Creole elite from politics, and to their concentration on elite posts in the administration, education and the economic sector, where they could still profit from their advantages of formal school graduation. Only after 1964 did tendencies towards a full removal of the political opposition awaken the resistance of the Creole inhabitants of the capital and the peninsula. Influential members of Freetown's Creole elite contributed to a paving of the way for Siaka Stevens to take political power. ${ }^{42}$ This shows that the particular culture of Creole activity from the capital remained influential during the interwar period, decolonisation, and into the post-colonial Sierra Leonean state. Creoles continued to influence strongly the ways in which political discourses were formulated, and they thus had an impact on the manner in which the different parts of Sierra Leonean society would describe themselves. The Temne were the first to borrow categories and concepts of group cohesion to present themselves as an ethnic group with a common destiny.

\section{Living at Knifepoint: The Silent Temne Majority in Northern Sierra Leone, $1820-1850$}

The experiences of Temne group identification in the period before the colonial conquest were therefore shaped by a complex interplay of relations to neighbouring linguistic communities, which involved cultural contact with Creoles in Freetown. Political entities were frequently fragmented. This situation needs to be contrasted with claims by Temne-speakers to have a common culture of political institutions, a common tradition of land rights and customs of land use, and various founding myths propelled into a legendary past. In Temne accounts collected in the early twentieth century, only the 'Bai' were regarded as sovereign political rulers, while the positions of 'Alkali', 'Pa Suba',

41 Wyse, Akintola, H.C. Bankole-Bright and Politics in Colonial Sierra Leone 1919-1958 (Cambridge etc.: Cambridge University Press, 1990), 133-62.

42 Allen, Christopher, 'Sierra Leone Politics since Independence', African Affairs 67(269), 1968, 305-29, 308, 314; Riley, Stephen, and Trevor W. Parfitt, 'Party or Masquerade? The All People's Congress of Sierra Leone', Journal of Commonwealth \& Comparative Politics 25(2), $1987,161-79$. 
and 'Santigi' were understood to be clearly subordinate functions. In the nineteenth century, however, such a vision was as idyllic and fictional as the idea of six 'original' Temne sub-groups, which is sometimes discussed in 'traditional' accounts. ${ }^{43}$ British travellers regularly obtained information about an earlier, more united Temne nation - but this was obviously what they were looking for! For some of the more ambitious Temne-speaking rulers, as in Port Loko or Masimera, this was also an occasion to formulate claims as informants. ${ }^{44}$

Organisation of access to land may explain the political fragmentation of Temne communities. Collective control over land, in the sense of the 'crown lands' of Senegambia, was rare. Land was mainly organised through its individual use and possession by free men, an arrangement in which the local rulers could rarely interfere. Such land practices are in contradiction to the practice of lambê that regards the land as principally leased by the rulers - a practice that had disappeared at least by the end of the nineteenth century. ${ }^{45}$ With regard to origin legends, it is striking that founding myths contained very little about autochtony (like for Wolof-speakers) or long-distance migration (like for Ewe-speakers). Some of the Sierra Leone Creoles, as discussed by a member of the Freetown elite, depicted the Temne as identical with the 'Mane' - but they relied, as 'authority' on this apparently vanished group, on the classic seventeenth-century account by the French merchant Jean Barbot, and attempted to bolster the position of their linguistic community by the alleged link to the legendary conquerors. ${ }^{46}$

Traditions collected by British administrators in the late nineteenth century appear to reflect the tense relations between Susu-speakers and Temnespeakers during a good part of this century: in fact, some Temne-speaking informants claimed that the Temne had been able to push the Susu coastwards over a period.$^{47}$ Esu Biyi, one of the important Creole informants of the 1910s, referred to such an account: it claimed that the Temne-speakers had formerly lived in the vicinity of the Rio Nuñez, namely in Melikori, but had been driven out by Susu and Mandinka groups. The categories employed, however, remain

43 Schlenker, C.F., A Collection of Temne Traditions, Fables and Proverbs with an English Translation;...(London: Church Missionary Society, 1861), iv-vi, 3-13; Biyi, Esu, 'The Temne People and How They Make Their Kings', Journal of the Royal African Society 12(46), 1913, 190-9, 192-3, 198-9.

44 Griffith, T.R., 'On the Races Inhabiting Sierra Leone', Journal of the Anthropological Institute of Great Britain and Ireland 16, 1887, 300-10, 304-5.

45 Anwyl, 'Timne', 47; Biyi, Esu, 'Temne Land Tenure', Journal of the Royal African Society 12(48), 1913, 407-20, 411.

46 Biyi, 'People', 191-192.

47 Anwyl, 'Timne', 37. 
vague. ${ }^{48}$ While the formulation of a history of origins with regard to the groups remains therefore sketchy, the evolution of Temne group sentiment, which had such a huge impact on the political panorama of the post-colonial country, must be sought in a long process of conflicts within pre-colonial and colonial experiences.

We can find information about Temne-speakers in European reports before 1787. The label 'Temne' existed already in the sixteenth century, but accounts concerning the Sierra Leone coast switch repeatedly between this and other labels. Accounts of major events, such as the so-called 'invasion' of the 'Mane', suggest that there may have been a different or overarching group identification described as 'Sape', but its long-term influence is unclear. ${ }^{49}$ Some slaves transported into the Caribbean by the British Royal Africa Company - present on Bance Island from 1678 - were sold as 'Temne' in the eighteenth century, but it remains unclear what this label referred to. ${ }^{50}$

In the first half of the nineteenth century, the British near-obsessive effort to create 'open trade routes', and to finish with slavery and the sale of slaves altogether, led to increased information on the 'hinterland' of Freetown. ${ }^{51}$ British administrators hoped to mediate in conflicts and to create zones of fertile production and of importation of useful trade goods, to benefit the interests of the metropolitan industry. Slowly, this gave an increasing impression of local solidarities. Initially, the missionaries of the Church Missionary Society were the main contact partners for Temne-speaking communities in the area of Port Loko or further northwards. The CMS organised teaching in the Creole villages of the Sierra Leone Peninsula, but also created mission stations in different parts of the 'hinterland' of Freetown, including in the Temne-speaking settlements such as Port Loko and, for a period, Magbele and Kambia. Missionaries were not really concerned with political relations, and they usually only interacted with different rulers when they had to travel overland and needed to receive permits and food rations. In the second half of the nineteenth century,

48 Biyi, 'Temne', 192-3.

49 Brooks, George E., Eurafricans in Western Africa: Commerce, Social Status, Gender, and Religious Observance from the Sixteenth to the Eighteenth Century (Athens/oH: Ohio University Press - London: James Currey, 2003), 167; Hair, 'Continuity', 254-5.

$50 \quad$ Rodney, History, 229; Hall, Douglas, In Miserable Slavery: Thomas Thistlewood in Jamaica 1750-86 (Kingston: University of West Indies Press, 1999 [1750-1786]), 135.

51 For an account of slave villages in the Port Loko area from the 1850 os to the 1870 s, see the report of active CMS missionaries in CMS, C A1/O 83/1, John Henry Davies, CMS native catechist, [Report from Magbele 1857] (without number), without date [1857], 4-5; CMs, $\mathrm{CA1} / \mathrm{o} 60 / 55$, Reverend Archdell Burtchaell, Six days itinerance in the Temne Country from Port Loko to Mangay (without number), 16 June 1879, 3, 7. 
'native pastors' educated by the mission partly replaced the white missionaries, but they did not get into the leading positions. ${ }^{52}$ In spite of the lack of interest of the CMS personnel in political matters, they were, however, interested in the linguistic affiliations of villagers in the region, as they were engaged in translating their catechisms into Temne, Susu, and Bullom.

Regional solidarities were changed in the second half of the nineteenth century by the decline of the Federation of Morea. The Almami had always had to create his own alliances with chiefs within his own federation. After 1850, this ruler and his allies found themselves in a weak bargaining position in negotiations with French and British diplomats who were attempting to establish a protectorate over Forékaria. For the Temne-speaking rulers, and their Sususpeaking or Limba-speaking colleagues, the room for manoeuvre increased. Local authorities from now on turned to the British administration in Freetown.

With the exception of certain groups during the succession in Morea and around the wars with the Freetown Colony after 180o, the different Temnespeakers involved in these wars had been little inclined to employ ethnic identifications as criterion for mobilisation. In this, the Temne-speakers of northern Sierra Leone were at a clear disadvantage in comparison with the Susu, and the Fulbe of the Fuuta Jallon Highlands. British travellers normally identified the Temne-speaking inhabitants of the Koya region as members of one homogeneous 'Timanee' tribe, but this tendency was clearly a simplification for European convenience. CMS missionaries touring these villages make it clear that their inhabitants did not normally speak about larger group solidarities. ${ }^{53}$

However, the Temne of Koya were faced with pressures exerted by the Freetown settlers, and needed strategies to cope with this situation. They gradually turned existing linguistic ties into categories according to ethnicity. As in the case of Port Loko, mobilisation under the ethnic label allowed conditions to be improved in war-torn Koya, in the face of a growing Creole settler presence. The behaviour of Temne-speakers on Bance Island, the small British settlement originally set up for slave-trading purposes, is instructive in this respect: to build a military alliance with different Temne-speaking leaders on the mainland in 1809 , they insisted on their common roots. ${ }^{4}$

52 Lynch, Hollis R., "The Native Pastorate Controversy and Cultural Ethno-Centrism in Sierra Leone 1871-1874', Journal of African History 5(3), 1964, 395-413, 409-10.

$53 \mathrm{CMS}, \mathrm{C} \mathrm{A1} / \mathrm{E}_{7}$ - 99, Johnson, CMs missionary, Journal of an Excursion taken by Mr. Johnson J.B. Cates, Wm. Tamba \& others round the Colony of Sierra Leone (without number), without date [January 1819], 24-5. 
Otherwise, on the European side, the vision of the Temne as a cultural and political bloc prevailed. British officials in Freetown were convinced that land questions between the Creole settlements under British rule and their neighbours in Koya, or problems existing between Freetown and adjacent communities, could be negotiated through general 'tribal' agreements. ${ }^{55}$ Some of the Temne-speaking chiefs understood this particular 'tribal character' of British interpretations and attempted to draw individual profit out of it. These chiefs in some negotiations claimed to have an authoritative voice to speak 'for all Temne': in 1819, the Temne-speaking headmen from Koya, Pa London and Ka Canko, attempted to improve their weak bargaining position, and thus to maintain some access to land in negotiations with the governor in Freetown, Charles MacCarthy. To bolster their standing in these negotiations they claimed to represent a 'tribal Temne King', Pa Naimbana. ${ }^{56}$

Such rhetorical tactics, which initially were no more than instrumental, had still little to do with the political realities in the coastal areas north of the Freetown Peninsula, where incursions by armed groups remained commonplace. Thus, in 1826, various coastal populations mobilised in a large alliance against the pillaging campaigns of a member of the local Tina family, Amurati, who, as a Dyula, had started to control a considerable part of the coastline. Bullom-speakers and Susu-speakers used ethnic arguments; Temne-speaking rulers who had entered this alliance only selectively, normally did not. Amurati was finally defeated by a 'multi-ethnic' coalition, and his own Tina kinship network let him down; it did not help Amurati to be a 'Mandinka', as other Mandinka-speaking chiefs joined the camp of his opponents. Ethnic allegiance was not a reliable factor. ${ }^{57}$

In the following decades, British intermediaries attempted to organise meetings, bringing together various groups. British officials intervened in the selection of the new ruler (Alkali) of Port Loko in 1825, and British arbitration was also decisive in 1826, when Almami Amura stepped down and a new ruler had to be elected..$^{58}$ European residents believed they mainly had to arbitrate between Mandinka-speaking and Susu-speaking rulers, and hoped that, in the

Council, Council Session (without number), 14 Oct. 1809, 1. Fyfe, History, 108-9, relates the riots on the island, but omits to mention the attempts at creating a Temne solidarity with mainland populations.

55 TNA, PRO, CO/267/47, MacCarthy to Bathurst ( ${ }^{\circ} 208$ ), 19 July 1819, 2.

56 TNA, PRo, CO/267/49, MacCarthy, Pa London and Ka Canko, Convention (without number), 5 May 1819 .

57 TNA, PRO, CO/267/72, Macauley, Governor of Sierra Leone, to Bathurst ( $\left.{ }^{\circ} 57\right), 4 \mathrm{July} 1826,1-3$.

$5^{8}$ TNA, PRO, CO/267/72, Macauley to Bathurst ( $\left.{ }^{\circ} 57\right)$, 4 July $1826,6-8$. 
meantime, the Temne-speaking rulers would accept and abide by these agreements. Indeed, the Temne-speakers initially retained a low profile in the conflicts about the internal relations within Morea.

However, constant warfare in the 1830 s, partly fuelled by slave-raiding, changed the whole political panorama. In 1836, the political situation in the triangle between the Sierra Leone Peninsula, the city of Forékaria and the Rokel River had become so insecure that a general peace conference was desirable to many of the local rivals for power. These leaders seem to have become exasperated with the permanent threat of destruction that hung over their communities. The governor of Sierra Leone, Henry Dundas Campbell, was chosen as a neutral intermediary, and he attempted to identify and invite the maximum number of different groups to negotiate.$^{59}$ The peace conference was held in the town of Magbele. Dala Modu Dumbuya, the Susu-speaking chief of Madina, most formidable ally of the British in the north and major spokesmen of the peace initiative, described the meeting as an 'all-ethnic conference': 'the foulahs, Soosoos, Bundues and all the countries join with the Timanees, and said we put our Country in Your [Campbell's] hands', Dala Modu stated. ${ }^{60}$ Most of the other participants also assured the British that this was a previously unknown inter-group initiative.

The British side was clearly too optimistic that a 'tribal' solidarity amongst the Temne would help to solve the conflicts. They believed that the Temne as one 'nation' or 'tribe' would be able to end the conflicts if they only wanted to. These misinterpretations explain in part the resulting confusion. ${ }^{61}$ A paradigmatic event was the destruction of the 'Forékaria Fence' stockade, where battles had continued. A column of Royal African Corps soldiers of West Indian origins and a local ruler, Bai Sherbro of Kafu Bullom, burnt down the place, with the British commander, Lieutenant Findlay, believing that this was necessary to expel 'foreign' marauders. ${ }^{62}$ This led to uproar amongst the allies of the defeated party at the peace conference, and Campbell had to set up for Findlay a local ad hoc court and to discuss with the different leaders their interpretations of local politics. The discussions confirmed that networks of different

59 TNA, PRO, CO/267/149, Campbell to Glenelg (without number), 19 May 1838, 1-2; Fyfe, History, $205^{-6}$.

6o TNA, PRo, CO/267/149, Campbell, Investigation relative to the Complaints of Namina Seacka, Bocary Soree and Maly and the destruction of the Fouricaria Fence ( $\left.{ }^{\circ} 865\right), 24$ April $1837,48-9$.

61 TNA, PRO, CO/267/149, Group of Freetown traders to Dala Mahomadu, Chief of Madina (without number), 21 Jan. 1837, 1.

62 TNA, PRo, CO/267/149, Campbell to Benwick, Captain of Royal African Corps (without number), 28 April $1837,1-3$. 
rulers, such as those of Fatima Brima of Port Loko or the Bai Sherbro, were essential in the region, not membership of local ethnic entities. The few instances of recourse to ethnocultural labels were largely confused (e.g. the British commander of the operation erroneously described the Susu-speaking general Dala Mahomadu as 'one of the leading men belonging to the Limba Army'). ${ }^{63}$ 'Limba' and 'Loko' were not present; the 'Loko' and their ruler, Bancha, were described as 'warlike' and dangerous; the 'Limba' as 'savages' and 'slave-catchers'. ${ }^{64}$ Mandinka-speakers occasionally described themselves as being a group apart, and they were threatened - as a particularly strong 'other' - by headmen and warriors from Port Loko and from the Kafu Bullom. ${ }^{65}$ Even so, at Forékaria Fence, one leader, Mali, as a Mandinka, cooperated with two Temne-speaking rulers, Namina Siaka and Boba Sori - as they pointed out when they testified as witnesses at the Magbele peace conference. ${ }^{66}$

Ethnic tropes were important concerning the Fulbe, who were conceived as a dangerous group, as the Almamis of the Fuuta Jallon were not only the masters of regional commerce, but also inclined to send punitive expeditions. There was no envoy of the ruler of Fuuta Jallon present in Magbele, but the fear of the 'Fulas' remained omnipresent. An important additional motive for the peace conference was to prevent yet another Fulbe incursion. ${ }^{67}$ But the winners of the peace conference were Susu-speaking communities of the northern riverine areas, who were not only successful in slowly conquering villages of Limba-speakers, but also in portraying these activities as defending themselves against dangerous 'savages' - while many of the rulers present were

63 Fyfe, History, p. 206, regards the background story as an ethnic war 'between Susu and Limba'. See also TNA, Pro, CO/267/149, Findlay, Lieutenant of Royal African Corps, [Detailed Report of Lieutenant Findlay] (without number), 20 April 1837, 7-8; TNA, PRO, $\mathrm{CO} / 267 / 149$, Findlay to Benwick (without number), 23 April 1837, 1.

64 TNA, PRO, CO/267/149, Campbell to Glenelg (without number), 19 May 1838, 12.

65 TNA, PRo, CO/267/149, Findlay, [Report of Operation to Fouricaria] (without number), 27 March 1837, 5-6; TNA, PRo, CO/267/149, Findlay, [Detailed Report of Lieutenant Findlay] (without number), 20 April 1837, 20; TNA, PRO, CO/267/149, Campbell, Investigation relative to the Complaints...( $\left.\mathrm{n}^{\circ} 865\right), 24$ April 1837, 103; TNA, PRo, CO/267/149, Copley, [Report] (without number), without date, 2.

66 TNA, PRo, CO/267/149, Abbott to Copley, both captains of Royal African Corps (without number), 9 April 1837, 1; TNA, PRO, CO/267/149, Findlay, [Detailed Report of Lieutenant Findlay] (without number), 20 April 1837, 18; TNA, PRO, CO/267/149, Findlay, Statement of Bogoro Sorey (without number), without date; TNA, PRO, CO/267/149, Campbell, Investigation...( $\left.\mathrm{n}^{\circ} 865\right), 24$ April 1837, 59.

67 TNA, PRO, CO/267/149, Investigation, 15; Howard, 'Trading', 28; TNA, PRO, CO/267/149, Campbell to Benwick (without number), 25 April 1837; TNA, PRO, CO/267/149, Campbell, Investigation...(n 865), 24 April 1837, 4. 
sceptical about the activities of the rulers further north, they at least agreed on the negative vision of Limba populations. ${ }^{68}$ Fatima Brima of Port Loko also was on the winning side: he managed to convince the British that he was a kind of spokesman of the Temne-speakers. During the negotiations in Magbele, the different sides used interpreters, although many individuals appear to have been well able to communicate in either language. The ostentatious use of competing languages during the deliberations was a ploy to mark group difference. ${ }^{69}$

The peace agreement of Magbele, signed by all regional leaders, brought only a temporary relaxation of tensions. Over the whole of the 1840 , the interest of the involved parties was not great enough to find a formula to ban the use of force. As long as life on a knife-edge continued from the point of view of most local communities, questions of ethnic hostilities were indeed not the decisive obstacle to a general peace: Temne-speakers fought Temne-speakers, Susu-speakers were engaged in warfare against other Susu-speakers, with only the 'savage' others, namely the Limba, being shunned as alliance partners in ways that were formulated through ethnic stereotypes. From the 1850s, however, successive waves of still more unbounded military violence emerged in the power vacuum left in the north by the decline of the federation of Morea. These regional events led to an increase in the use of ethnic formulae.

\section{'Susu Invasions', Larger Alliances, and the Integration of the Temne into the British Sphere of Power, 1850-1875}

On the whole, the situation in the riverine north of Sierra Leone had remained unstable in the first half of the nineteenth century, and changing military alliances and the predominance of small political units in the area prevented solidarity among Temne-speakers. Identifications in the region were relatively fluid. In regions such as Kolifa Mayoso, the clan and family histories of individuals indicated mixed Temne, Susu, Koranko and other origins, giving a picture that resisted clear distinctions and stereotypes. ${ }^{70}$

The battles for the city of Kambia and the adjacent region in the 1850 s constituted a turning point, as they stirred up a wave of cooperation between

68 TNA, PRO, WO/32/7620, War Office, Intelligence Branch, Précis of Information concerning the Colony of Sierra Leone (without number), 1887, 8.

69 TNA, PRO, CO/267/149, Campbell, Investigation...(n॰ 865), 24 April 1837, 6, 70-1, 73, 92-3, 111.

Dorjahn, 'Migration', 36. 
Temne-speakers. This led, just before the British conquest starting in the $187 \mathrm{os}$, to a clearer feeling of mutual solidarity between members of these communities. Such experiences coincided with the effects of Temne immigration into the urban area of Freetown, where the colonial administration increasingly pressured immigrants into following the category of 'tribal' identification. Already in the decades before, British clerks had begun to count the escaped slaves from adjacent regions according to a simplified ethnic background model: they were defined as 'Kosso, 'Temne', 'Koranko' or 'Sherbro'. In the second half of the nineteenth century, the same model was increasingly applied to the free immigrants coming to the colony as workers. This administrative effort for 'authenticity' finally spilled back into the different rural communities. During the internecine warfare in Sierra Leone that was so typical of the 185 os and 186os, local populations and their leaders used such concepts to build their own alliances. ${ }^{71}$

The conquest of the important town and trade post of Kambia in the area of the Great Skarcies River, by a well-organised war band led by two Susu-speaking leaders - Satan Lahai and Bori Lahai - in late 1857 , had an enormous impact in the region. As Christopher Fyfe has pointed out, Satan Lahai had Temne relations through his mother. However, in $1857 / 58$, this fact does not seem to have played a role: the Temne-speaking chiefs of the region constantly described the other side as 'Susu invaders', and Satan Lahai relied mainly on Sususpeaking warriors. Significantly, in 1876, the same Satan Lahai presented his case in an entirely different way - as I will later discuss. ${ }^{72}$

The army units of the Lahais not only took the town, but also controlled large parts of the area between the Skarcies Rivers and the Colony of Sierra Leone. Until mid-January 1858 , Temne-speaking headmen in the region attempted to create an alliance against the Lahais, but this was unsuccessful, and the latter's troops were still making progress. Only with British support did these rulers manage to expel the Lahais from Kambia, which was burnt to the ground during the battle, and to drive them back into the northern interior. Their opponent destroyed the mainly Temne-speaking settlements of Rogbari and Rokon at the Rokel River. ${ }^{73}$

71 TNA, pro, CO/267/261, Hill, Governor of Sierra Leone, to Lytton, British Secretary of State for the Colonies ( $\left.\mathrm{n}^{\circ} 129\right)$, 13 July 1858,5 .

72 Fyfe, History, $283-4$, who claims that Satan Lahai is very likely to have had a 'Temne mother'.

73 TNA, PRo, CO/267/260, Hill to Labouchere ( ${ }^{\circ} 23$ ), 13 Feb. 1858, 6, 17; tNA, Pro, $\mathrm{CO} / 267 / 260$, Wise, British Commander at the Guinea Coast, to Grey, British admiral, Reporting operations conducted against the Sooso Chiefs by H.M. Naval Forces up the Rr. 
Temne-speaking communities in the region had continued with plundering campaigns ever since the peace talks at Magbele. However, the impact of the temporary loss of two major Temne-speaking population centres, and the threat by the Lahais and their followers, reawakened the idea of Temne solidarity that had already been visible as a possibility during the talks at Magbele. As a common base for an alliance, the idea that they defended Temne territory against a 'foreign' invader was a useful kind of commitment for local communities. This strategy was, all in all, remarkably successful, although the coalition remained, in practice, fairly dependent on British military support. ${ }^{74}$ This alliance, based on ideas of ethnic solidarity was visibly expressed in the existence of a joint command of different Temne chiefs during the campaign which was an unusual step in the politically fragmented rivers of northern Sierra Leone. ${ }^{75}$ This command was not too efficient, but in the end the coalition marched against Romangi, the settlement of one of the paramount chiefs of the alliance, and retook it from the troops of the Lahais in June 1858, with British help and after protracted struggles. ${ }^{76}$ This success illustrated the usefulness of the alliance.

In the meantime, the new politics of 'Temne unity' also had an effect on the diplomatic front, as the Temne-speaking chiefs of the alliance were able to convince the British side that they had the authentic claim to rule over Kambia. The Lahais had insisted, on the contrary, to the governor of Sierra Leone that their family had an ancient right to rule over the city; but chiefs from the coalition successfully challenged this view through the simple notion that Kambia was a 'Temne city'! Both amongst the British authorities and British and Creole merchants, the idea prevailed indeed that Kambia was a 'Temne city' that had to be protected against 'Susu raiders. ${ }^{77}$ For the British, the rhetoric of an allTemne campaign was all the more impressive, since in other conflicts in the region, such as those over the control of the former Federation of Morea between Sumbuya, Moralo, and Forékaria, ethnic terms played no role at all. ${ }^{78}$

Scarcies on the 29th, 3oth \& $315 t$ of Janr. \& the 1st, 2 nd \& 3 rd of February 1858 (without number), 5 Feb. 1858, 2-3, 7 . TNA, PRO, CO/267/260, Hill to Labouchere $\left(\mathrm{n}^{\circ} 3\right), 1 \mathrm{Jan} .1858,2-3$.

75 TNA, PRO, CO/267/260, Wise to Grey, Reporting operations...(without number), 5 Feb. 1858, 8.

76 TNA, PRO, CO/267/260, Hill to Stanley ( $\left.\mathrm{n}^{\circ} 117\right)$, 26 June $1858,2-3$.

77 TNA, PRo, CO/267/260, Hill to Bori Lahai (without number), 16 Jan. 1858, 1; TNA, PRo, $\mathrm{CO} / 267 / 260$, Hill to Satan Lahai (without number), 16 Jan. 1858, 1; TNA, PRO, CO/267/260, Pratt, Williams, Spilsbury, Walker, Kidd, and Drake, members of the Committee of the Mercantile Association in Freetown, to Hill (without number), 17 Feb. 1858, 1.

78 TNA, PRO, CO/267/260, Hill to Stanley ( $\left.{ }^{\circ}{ }^{118}\right)$, 28 June 1858 , 1-2; TNA, PRO, CO/267/261, Hill to Stanley $\left(\mathrm{n}^{\circ} 123\right), 8$ July $1858,1-2$. In contrast, in earlier documents the rulers of 
It seems that the formulation of a Temne group identification found itself reinforced through commercial activities of that period. Christopher Fyfe has emphasised this point in relation to growing tensions between Temne-speaking peddlers and Freetown merchants, the latter belonging mainly to the group of the 'Aku' who originated from former slaves from the Bight of Biafra. In those conflicts, the Temne-speakers gave an impression of evolving into a larger community. ${ }^{79}$ The British regarded this process both as a confirmation of a 'tribal' interpretation of local politics, and as problematic, as it collided with the more aggressive strategy now being implemented by the colonial administration against the populations of Koya, neighbours of the urban area of the Sierra Leone Peninsula. After the battle of Kambia, the British officials in Freetown proceeded to a new peace conference, which strove to underline the character of ethnic harmony in the north.

However, the usefulness of being counted as 'Temne' was quickly realised by other leaders. A number of rulers whose communities were not Temnespeaking claimed they needed to be counted as part of the larger Temne group. Kala Modu, a chief of Madina on the Bullom Shore, insisted on being included in the overall peace procedures and complained that the treaty was too exclusive. ${ }^{80}$ The new sense of group unity among the Temne-speakers thus had its attractiveness among neighbouring rulers, who attempted to enter the networks in spite of ethnic solidarity.

By contrast, some Temne-speaking individuals, with experience as mercenaries further southwards, tried to create for themselves their own strongholds in the southern coastal zones of Sierra Leone. In 1858, Pa Lamina, a former resident of Bumpe and Sembehun and successful leader of a warrior group, claimed from the British authorities the paramount chieftaincy of what he called the whole of the 'Mende territory'. The British were sceptical and did not take these claims too seriously. It later came out that the self-styled ruler was perfectly Temne-speaking and had an obvious Temne name! ${ }^{81}$ Such initiatives went against the British logic of categorising communities through ethnic

Morea normally described themselves as 'Mandinka' chiefs, see TNA, PRO, CO/879/15, African Confidential Print No. 173, Almami Amura Turé; Gabbidon, and Savage, the latter being traders on the island of Matakong, [Declaration] (without number, Enclosure No. 5), without date [1825], 1. On the evolution of Morea, see Skinner, Lawson, 72-77. TNA, Pro, CO/879/14, African Confidential Print No. 159, Rowe to Michael Hicks Beach $\left(\mathrm{n}^{\circ} 100\right.$, as $\mathrm{n}^{\circ} 12$ in series), 28 June $1878,2-3$; Fyfe, History, 415-6.

8 TNA, PRO, CO/267/261, Hill to Lytton ( $\left.{ }^{\circ} 144\right)$, 30 July $1858,1-2$.

81 TNA, PRO, CO/267/261, Pa Lamina, The humble Petition of Pa Laminah Native Chief of the Mendi Nation residing at Sanahu, in the Mendi Country (without number), 14 Sep. 1858, 2, 8; TNA, PRO, CO/267/261, McCormack to Hill (without number), 16 Oct. 1858, 3. 
labels, and European officials feared 'unauthentic' rulers, who were quite contemptuously called 'robber chiefs'. ${ }^{82}$

In consequence, the 1850 s and 1860 s saw two contradictory tendencies. Caught in a web of violent conflicts, and under the influence of the British authorities who remained adamant in their belief that they had to achieve, ultimately, the opening of interregional trade routes, the long-established dynasties such as those in Morea, but also the more powerful individual rulers like those in Port Loko, lost their remaining control over the regional warfare. This was a good opportunity for leaders of 'war gangs' to establish their own strongholds in the area. Similar processes had started earlier in the south of Sierra Leone, where the political entities were even weaker. In the north, on the contrary, we find at first other developments that had the reverse effect. Above all, the impression created by the invasion of Susu-speaking raiders under the Lahais had an impact far stronger than the expressions of a general weariness of warfare that had characterised the peace negotiations of the 1830s. In the late $185 \mathrm{os}$, the worries about an expansion of dangerous, Susu-speaking war parties led for the first time to a more sustained movement of Temne unity. For the time being, these trends towards a new solidarity, however, remained fragile: many Temne-speaking leaders of armed groups preferred the alternative of themselves aspiring to a primary position as war leader.

The conquest of political power by such rulers constituted a challenge for the British, who had to explain why overarching group identifications were so unsuccessful. In the most well-known case, it was even worse: the new rulers attempted to formulate their territorial claims through a sub-group identity that of the 'Yoni' - instead of referring to broader Temne ethnic sentiment. This confused the British, who held that many of the adversaries in the battles to come, like the Yoni and the populations of Masimera, were just 'families of the Timmanee tribe. ${ }^{83}$ The Yoni war, therefore, was a watershed as regards influencing and understanding group identifications of the Temne.

\section{Group Polarisation and Warfare: The Yoni Affair and the Hut Tax War $\left(\mathbf{1 8 7 5}^{-1898)}\right.$}

After a less active period in the 1860 s and 1870 , the British administration in Freetown attempted to formalise its presence in the surroundings of the Sierra

\footnotetext{
82 TNA, PRO, CO/267/270, Hill to Duke of Newcastle ( $\left.{ }^{\circ} 34\right), 12$ March $1861,2-3$.

83 TNA, PRo, CO $/ 879 / 15$, African Confidential Print No. 173 , Rowe to Hicks Beach $\left(\mathrm{n}^{\circ}\right.$ 9o, as $\mathrm{n}^{\circ} 2$ in series), 22 Nov. 1878.
} 
Leone Peninsula during the following decade. The French success in bringing the territory of Forékaria - the former heartland of the 'Federation of Morea' - under their control alarmed the British. ${ }^{84}$ This provoked a more aggressive appearance of British representatives and a more marked approach to the classification of communities. To bring order to their ideas of the composition of groups in the Sierra Leonean territory, the Freetown Native Affairs Department became quite active in collecting more (and more detailed) accounts of informants that seemed useful for an understanding of group loyalties in the region.

In the southern and eastern parts of current-day Sierra Leone, Mendespeakers were engaged in crafting regional alliances. Temne-speaking communities of the north were after only a short period well-informed about those events, as political developments in the whole of the coastal region were reported and widely discussed. ${ }^{85}$ In Koya, the region adjacent to the Sierra Leone Peninsula, the activities of Loko-speaking refugees led to a situation in which Temne appeared to fight Loko. This type of tension had disappeared for a good part of the period after 1837, and only now reappeared in the spotlight; in this context, the Loko-speakers were described by their Temne-speaking neighbours as an entirely distinct 'people'. ${ }^{86}$ Koya's Temne-speakers had, in the late 1870 s, and in consequence of conflicts between settlements, been engaged in capturing and selling as slaves a number of the inhabitants of some Loko communities. These acts then led to retaliation, and the conflict intensified friction in the whole region, as a good part of Koya's Temne-speakers and Lokospeakers lived in the villages in question, and it was quite difficult for both observers and the populations themselves, to find categories of distinction. ${ }^{87}$

Around the Temne-speakers in the north, there were also important community changes taking place. In Sumbuya, the area of the northern rivers around Wonkafong and Moribea, it was Susu-speakers who pushed considerable numbers of Bullom-speaking individuals out of the region. However,

84 Schnapper, Bernard, La Politique et le Commerce Français dans le Golfe de Guinée de 1838 à 1871 (Paris - The Hague: Mouton, 1961), 235-9.

85 TNA, PRo, CO/879/10, African Confidential Print No. 114, Rowe to Carnavon, Secretary of State for the Colonies ( $\mathrm{n}^{\circ} 89 \mathrm{~A}$.), 19 June 1876, 4; TNA, PRO, CO/879/11, African Confidential Print No. 139, Rowe, Memorandum by Dr. Rowe, C.M.G. (without number, Enclosure in No. 36), 1st Aug. 1877, 2.

86 TNA, Pro, CO/879/15, African Confidential Print No. 173, Bome Rufa and Bome Warrah, 'Queens of Quiah'; Balu Modu, Chief of Koya, and others, Address of the Queens of Quiah and other Chiefs (without number), 22 Jan. 1879; TNA, PRO, CO/879/15, African Confidential Print No. 173, Lawson to Rowe (without number, Enclosure No. 5), 6 Jan. 1879, 3.

87 TNA, PRO, CO/879/15, African Confidential Print No. 173 , Rowe to Hicks Beach $\left(\mathrm{n}^{\circ} 200\right.$, in series as No. 11$), 18$ Dec. 1878, 1-2. 
Temne-speakers, like the Susu-speakers, were gaining ground. The presence of the Temne-speaking Digsing in the interior of the Samu region was a visible sign of the expansion of the Temne language and of Temne-speakers in the second half of the nineteenth century. ${ }^{88}$ It also shows, together with the events of Sumbuya, that Sierra Leone was, only two decades before the creation of formalised colonial rule, a region where the migration of armed groups was still possible, and even an increasing phenomenon, quite unlike Senegambia in the same period.

It is interesting to note what, in the years leading up to this, became of Satan Lahai. In the 185 os, this leader had acted as a feared 'Susu warrior chief'. In the 1870 s and early 188 os, he not only maintained his base as ruler of Rowula but he increasingly appeared as member of a political ensemble (and network) of Temne-speaking chiefs! He used this as an act of political propaganda. ${ }^{89}$ During the peace talks in the Skarcies Rivers region in 1876 , the ruler of Rowula presented himself as spokesman of Temne-speaking fellow rulers, such as Almami Lusani of Digsing. Lahai also occasionally presented himself as a 'delegate' of Bai Farima of Kambia. ${ }^{90}$ In 1878 , he was therefore sometimes described, by the British and even by some of their informants, as 'Temne'!11 In 1881, Satan Lahai, like 'other Temne chiefs', was criticised for carrying war from the Temne into the Susu territory. ${ }^{92}$ Finally, Lahai was able to profit from these more flexible descriptions to act as a mediator between the Limba-speakers and the Susu-speaking population of Kukuna, who were in a violent conflict regarding the question of refugee slaves. ${ }^{93}$

88 TNA, PRO, WO/32/7620, War Office, Intelligence Branch, Précis of Information concerning the Colony of Sierra Leone (without number), 1887, 8.

89 TNA, PRo, CO/879/17, African Confidential Print No. 214, Bokari, [Declaration] (without number, Enclosure 3 in No. 104), 9 July 1880.

90 TNA, PRO, CO/879/10, African Confidential Print No. 114, Samuel Rowe, Governor of Sierra Leone; Almami Satan Lahai of Rowula; Bai Farima of Magbeti and Kambia; and other chiefs, Agreement signed by the Chiefs of the Scarcies Rivers on the 1oth June, 1876. (without number), 10 June 1876; TNA, PRO, CO/879/14, African Confidential Print No. 159, Rowe to Hicks Beach $\left(\mathrm{n}^{\circ} 100\right.$, as $\mathrm{n}^{\circ} 12$ in series), 28 June 1878,3 . TNA, PRo, CO/879/14, African Confidential Print No. 159, Status of Parties to the Agreement made at Kambia, Great Scarcies River, on the 27th April 1878, between the Timmanees and Soosoos. (without number, Enclosure 6), without date, 1.

TNA, PRo, CO/879/18, African Confidential Print No. 226, Streeten to Almami Satan Lahai, 'king of Rowula'; Bai Farima, 'king of Kambia und Magbeti'; Bai Inga, 'king of Small Skarcies' ( $\mathrm{n}^{\circ}$ 1, as Enclosure 5. in No. 27.), 4 Jan. 1881.

93 TNA, PRO, CO/879/14, African Confidential Print No. 159, Proceedings of a Meeting held at Kambia, Great Scarcies River, 24th April 1878 [25th April 1878]. (without number), without date, 6 . 
Other 'Susu' were also flexible about operating in collaboration with different sides, in clear contrast with the picture of a fundamental Temne-Susu antagonism, which the British believed themselves to be faced with. Sankong, another Susu-speaking warrior leader, appeared as an important ally of Lusani of Digsing, and Karlilu of Bashia also sided openly with Temne-speakers. ${ }^{94}$ All in all, while the Temne-speakers had shown their intention, between the $1850 \mathrm{~s}$ and the 1870 os, of selling themselves to the British as a homogeneous population, Susu-speakers of the north were seriously threatened by fragmentation. ${ }^{95}$ The rulers in opposition to Bokari in Forékaria, while conceding that Morea was the home of a population different 'from their neighbours, the Timmanees and Soombuyahs on the north and south', insisted that there was no central power in the country, and that indeed the Susu-speakers should be seen as being divided into different 'tribes' ${ }^{96}$

As the Temne-speakers of Digsing felt threatened by the growing presence of Susu-speaking war leaders in their region, and were determined to defend their autonomy, and as Satan Lahai was again, in 1876, actively expanding his own area of influence, the Temne-Susu antagonism appeared again to be at a new peak. ${ }^{97}$ This was also visible in new forms of diplomatic interaction promoted by the British: agreements were now read in Susu, Temne, and Limba, while before they had mainly been presented exclusively in Temne. This reflected the progress that specialised British officials had made with proficiency in the latter two languages, but it was principally an expression of a

94 TNA, PRo, CO/879/11, African Confidential Print No. 139, Memorandum on French and English Treaties with Chiefs of the Moriah and Samu Countries (without number), without date, 1; TNA, PRO, CO/879/14, African Confidential Print No. 159, Rowe to Michael Hicks Beach $\left(\mathrm{n}^{\circ} 100\right.$, as $^{\circ}{ }^{\circ} 12$ in series $)$, 28 June 1878, 3; TNA, PRo, CO/879/14, African Confidential Print No. 159, Bai Farima of Magbeti and Kambia; Satan Lahai, of Rowula, in the Casseh Country; and others, Agreement made at Kambia, Great Scarcies River, the 27 th day of April 1878, between the Timmanees and Soosoos and the Chiefs of Surrounding Countries. (without number, Enclosure No. 2), 27 April 1878, 1.

95 TNA, Pro, CO/879/15, African Confidential Print No. 173, Satan Dawoda and others, [Statement] (without number, Enclosure No. 4), 18 July 1879, 2.

96 TNA, Pro, CO/879/11, African Confidential Print No. 139, Rowe to Carnavon ( ${ }^{\circ} 148, \mathrm{n}^{\circ} 49$ of series), 29 Sep. 1877, 3; TNA, PRO, CO/879/17, African Confidential Print No. 206, Lawson, [Installation of Alimamy Bokharry] (without number, Sub-Enclosure No. 11), 3 Nov. 1879; TNA, PRo, CO/879/17, African Confidential Print No. 206, Notes, Geographical and Political, on the position of the French port at Binty in the Mellicourie River, on the Kissi Kissi Country, and on the Native Tribes on its Borders (without number, Sub-Enclosure No. 13), 3 Nov. 1879. TNA, Pro, CO/879/14, African Confidential Print No. 159, Rowe to Hicks Beach $\left(\mathrm{n}^{\circ} 45\right.$, as $\mathrm{n}^{\circ} 2$ of series), 21 April 1878. 
deeper awareness of the group-building role of these idioms. ${ }^{98}$ However, the apparently clear antagonism was again superseded by other interests, and by engagement in plunder. The town of Bileh on the Great Skarcies River, a local centre of Islamic scholarship, was burnt down during the war although both sides spoke in a reverential manner of the school lessons in Muslim scripts and consequently had ample reasons to spare the teachers. ${ }^{99}$

In the early 1880 s, with the battles in the Skarcies Rivers region coming to a halt, the momentum of inter-Temne cooperation in the north seemed to disappear. Given the absence of notable threats - Susu-speaking communities were occupied in local warfare amongst 'themselves'; the rulers in Forékaria were fairly weak and engaged in a conflict to decide for or against a French protectorate; the Fuuta Jallon had, with internal wars and the campaigns of Samori Touré in the interior of West Africa, been increasingly distracted from any interest in the coastal regions - ethnic difference was obviously not of a sufficiently great attraction to be a guiding principle. Only in situations of the most extreme emergency had it been tested as a useful strategy; now, it again became obvious that pan-Temne solidarity did not help villagers in smaller conflicts. ${ }^{100}$ Instead, as had already been the case in the late 186os, individual Temnespeaking leaders took the opportunity to create for their own power bases.

The most successful process of creation of such a local armed power-base occurred in a region more than a hundred kilometres east of the Sierra Leone Peninsula, in the so-called 'Yoni Country'. In 1885, a group of warriors formed an aggressive alliance with other local war groups. Over the next two years these warriors intensified their engagement in plundering campaigns in the surrounding lands. We do not find any stronger centralised power behind this Yoni expansion. Since 1879, the Yoni group had no longer had a Bai Sherbro, which had during former decades been a form of 'paramount chief'. Although this position had never fulfilled the role of a 'supreme ruler' as imagined by British officials, the Bai Sherbro had been, in the case of military conflict, a coordinating force. However, the Yoni group did not seem to need such a ruler to be successful in warfare. The different local leaders, informally headed by Kapra Toli of Ronieta and Pa Kundi of Makundu, organised with huge success

98 TNA, PRo, CO/879/14, African Confidential Print No. 159, Rowe to Hicks Beach $\left(\mathrm{n}^{\circ} 46\right.$, as $\mathrm{n}^{\circ} 2$ of series), 29 April 1878, 3 .

99 TNA, PRo, CO/879/14, African Confidential Print No. 159, Rowe to Hicks Beach $\left(\mathrm{n}^{\circ} 84\right.$, as $\mathrm{n}^{\circ} 9$ in series), 14 June 1878,2 . On Bileh's function, see Skinner, 'Islam', 55 .

100 CMS missionaries reported in $1879 / 80$ on a good number of villages in the region of Magbele and Port-Loko, from which all the inhabitants had fled; see CMs, C A1/O 29/7, Alley, Journal Jan. 1st-March 31. 1880 (without number), without date, p. 18. 
an alliance that engaged in successful pillaging across the whole of the region. In these activities, the Yoni troops showed no respect for the 'Temne identity': in 1878 , they had destroyed Magbele, the once important town centre and symbolic place of nascent Temne unity during the $1836 / 37$ peace conference. ${ }^{101}$ Furthermore, while the Yoni managed to include in their alliance Bai Simera of Rokon and some other important Temne-speaking leaders, they never had any ethnic programme.

The coalition of their opponents, which had been created under British influence, mostly had members who were not Temne. These included mainly Mende-speakers, but also the odd chief from the Sherbro. However, some members of the anti-Yoni alliance, such as the participating rulers of Koya, were Temne-speakers. Their participation against the Yoni was partly the expression of their dependence on Freetown as they were held to fulfil the terms of an earlier peace agreement, but their presence gave the anti-Yoni coalition a clear non-ethnic character. ${ }^{102}$ In the description of subsequent events, the perception of British commanders in Freetown was evidently distorted. Seeing the power within this part of the Temne 'tribe' as having been 'highjacked' by 'robber chiefs', the British were eager to 're-establish' what they regarded as 'traditional systems'. They believed that the defeat and removal of Kapra Toli and of Pa Kundi were appropriate steps to return the Yoni to their proper place within the Temne community. ${ }^{103}$

However, when the British Commander, Colonel Francis de Winton, advanced in 1887 to Mafengbe and started to defeat the Yoni leaders in battle with the mixed group of allies under his command, he quickly learned that local populations did not at all interpret the conflict according to ethnic categories. ${ }^{104}$ Therefore, the British also tended to deal with the different groups of Temne-speakers under other, regional labels such as 'Masimeras' or 'Mabangs'. Some officials reporting to the Secretariat of Native Affairs were quite afraid of a future 'alliance between Yonnis and Timanee'; in which they showed their failure to understand that the Yoni were themselves Temne-speakers! 105

\footnotetext{
101 TNA, PRO, CO $/ 879 / 15$, African Confidential Print No. 173 , Rowe to Hicks Beach $\left(\mathrm{n}^{\circ} 192\right.$, as $\mathrm{n}^{\circ} 3$ in series), 28 Nov. 1878 .

102 TNA, PRO, WO/32/7620, War Office, Intelligence Branch, Précis of Information concerning the Colony of Sierra Leone (without number), 1887, 11-3.

103 TNA, PRo, WO/32/7620, Edward Stanhope, British Secretary of War, to Colonel F. de Winton ( ${ }^{\circ}$ 074/419), 21 Oct. 1887.

104 TNA, PRo, WO/32/7620, De Winton to War Office (without number), 15 Nov. 1887; Fyfe, History, 475-6, gives little background information about the British view on communities at the River Rokel.

105 TNA, PRO, WO/32/7620, De Winton to War Office (without number), 22 Nov. 1887, 1, 3.
} 
Only when the fighting became more intense, and when they stood with their backs to the wall, do the Yoni appear to have made appeals for joint identification with a larger Temne community. They obviously hoped to obtain, at the last possible minute, increased support from other Temne-speaking rulers in spite of their devastating defeats. Nevertheless, at this moment the war was already nearly lost after the destruction of Mafokoya and the fall of Ronieta. Through their new, pan-Temne rhetoric, the Yoni leaders seem to have kept the rulers of Masimera and Marampa in their camp until the very end of the hostilities - British officials were quite surprised to find them amongst the enemies, the more so as those chiefs had remained formal allies of the British governor in Freetown! Here, the British clearly underestimated the capacity of Yoni chiefs to mobilise fellow Temne-speakers through arguments of a common ethnic identification; the British side had thought that all 'Temne' would turn against the 'robber chiefs'. ${ }^{106}$ However, in the last phase of the struggle, when under immediate military pressure, the 'Yoni' successfully employed 'Temne' group solidarities. This situation of alliances clearly points to fault lines defined through ethnic affiliation. Only when the British pushed hard to destroy the rest of the dispersed Yoni units, did some Temne-speaking chiefs try to return to the British camp. One such was Bai Simera, who claimed that the Yoni had alienated him by killing his son. ${ }^{107}$

Over the following years, ethnic solidarity again became more feasible as a motive for taking up arms. On the occasion of peace talks in the Rokel River region, Pa Suba and other Temne-speaking participants insisted categorically that, as a first step to an agreement, all Mende troops be withdrawn from the region. To 'reintegrate the Yoni' into the larger Temne community, it seemed adequate to define a common enemy: 'the Mende', who were now described as stereotypical opponents. ${ }^{108}$ Also, the assembled Temne-speaking chiefs claimed the right to reinstate Sey Masa as a fellow 'Temne' Bai Sherbro of the Yoni area. This was despite the fact that this act was in open contradiction to

106 TNA, PRo, WO/32/7620, De Winton to War Office (without number), 8 Dec. 1887, 1; TNA, PRo, WO/32/762o, De Winton to War Office (without number), 9 Dec. 1887, 1-2.

107 TNA, PRO, WO/32/7620, Ernest Parkes, Secretary of Native Affairs of Sierra Leone, Notes of Interview between Sir Francis de Winton and Bey Simmerah, King of Masimera, and the Chiefs of Masimera, Marampa, and Kwaia, 4th December 1887 (without number), 4 Dec. $1887,2$.

108 Different Mende chiefs, including Bai Lal of Malal and Madam Yoko, also showed a common group profile on that occasion: they would send 'Mende envoys' and formulate demands on behalf of the whole ethnic community, see TNA, PRo, CO/879/29, African Confidential Print No. 361, Hay, Governor of Sierra Leone, to Knutsford ( ${ }^{\circ} 375$, as No. 13 in series), 20 Nov. 1888. 
earlier proceedings of elections of rulers in the region, as only 'the Yoni' had been called upon to designate their new leaders. The assembled chiefs argued that, as representatives of 'Temne groups', they had the right to decide over the future of a community that was regarded as having a part in the process. ${ }^{109}$ There was a widespread feeling that the whole affair, although mediated by the British, had been resolved in the end by 'Temne' group solidarity. ${ }^{110}$

This process led to a new dimension of Mende-Temne antagonism. While, as we have shown, some group stereotypes had previously existed, open hostility on ethnic terms had been scarce (which was also partly due to geographic distance). ${ }^{111}$ In 1891, the trend was confirmed: during negotiations for another regional peace agreement held in Taiama, and sponsored by the British governor, James Shaw Hay, mutual accusations between 'Temne' and 'Mende' were very present. ${ }^{112}$ There was a clear potential for this conflict to transform into a larger and ethnically motivated war.

However, the Hut Tax War of 1898 interrupted this trend. There has been broader research on this particular event, which led to effective British conquest, and which need not be reiterated here. It is important to point out that the rebellion against increasing British control and new tax demands had a double face. First, it was an anti-colonial war of several local rulers against the British, but also a generational and social struggle. Moreover, the colonial power had relied heavily, in its organisation of an efficient frontier police during the 1880 s and 189os, on the employment of immigrants from the 'hinterland' of Sierra Leone, many of these being of lower social status or even descendants of slaves. The revolt exploded when these policemen quite aggressively voiced the British demand for a generalised tax. ${ }^{113}$ Second, the rebellion

109 Finally, the decisive conference was, unsurprisingly from a symbolic perspective, held at Magbele, and was indeed an exclusive 'Temne affair', see TNA, PRo, CO/879/29, African Confidential Print No. 361, Parkes, List of Chiefs and Santiggies (Principal men) present at Meeting at Mabelin on the gth instant, when Almamy Conteh was formally handed over to his people. (without number, Enclosure in No. 36.), without date; and TNA, PRO, CO/879/29, African Confidential Print No. 361, Parkes, Notes of Conversation between His Excellency Governor Hay, C.M.G., and Chiefs at Magbelin, at meeting on the afternoon of Sunday the 9th December. (without number, Enclosure 2 in No. 36), 10 Dec. 1888.

110 TNA, PRO, WO/32/7620, De Winton to War Office (without number), 21 Nov. 1887, 1-2.

111 It appears difficult to prove Kup's claim that there was a huge Mende invasion in northern Sierra Leone at the end of the eighteenth century, see Kup, History, 155-6.

112 Garrett, G.H., 'Sierra Leone and the Interior, to the Upper Waters of the Niger', Proceedings of the Royal Geographical Society and Monthly Record of Geography, New Monthly Series 14(7), 1892, 433-5, 453 .

113 Hargreaves, 'Establishment', 64. 
was a result of the permanent tensions between 'Creole' merchants and the populations of Port Loko, who felt insulted by the aggressive behaviour of these Creole resettlers and at a disadvantage in trade.

I will look in more detail later at changing mentalities in the town of Port Loko during the Hut Tax War. In any case, it is remarkable that it was not only the British who regarded the revolt as a 'Temne uprising. In fact, local communities who were not Temne-speakers attempted to remain neutral because they did not want to be drawn into a 'Temne affair'; several of their chiefs were eager to demand a possibly lucrative role as mediators because of not being Temne, as was the case with the Limba leader Suluku from Bumban. ${ }^{114}$ In the end the rebellion spread into the Mende-speaking regions, but this was at a different stage, and it was now impossible to create a larger alliance between Mende-speaking and Temne-speaking leaders.

In 1898 , not only were the firepower and military skills of northern Sierra Leonean communities insufficient to sustain battles with British troops, but even a charismatic war leader such as Bai Bureh, of Loko origins but a longstanding leader of Temne-speaking mercenaries, was incapable of keeping the ranks of the troops together after the first heavy defeats. ${ }^{115}$ Even so, ethnic mobilisation was an obvious tool. In a follow-on from the 'Yoni War', Temnespeakers had finally begun to appreciate the ethnic dimension of Temne-ness as a welcome means of mobilising the different local communities. After the defeat of 1898 , these war solidarities could partly be translated into principles of local organisation. For the part of the colonial rulers, the creation of 'native districts' of a new protectorate worked these existing group affiliations from war periods into the tissue of the emerging civil structures of colonial rule.

\section{Chieftaincy and Reorganisation in the Protectorate Period: The Case of the Northern Province (1898-1945)}

The end of the Hut Tax War profoundly changed the political and social conditions of community life in northern Sierra Leone. The creation of the Protectorate and of official provinces gave the initiative to European officials. Moreover, British 'pacification' led to a situation in which local groups, having formerly coexisted in a situation of rather unorganised and frequently bloody rivalry, now had to live alongside one another under the rule of paramount

\footnotetext{
114 Abraham, Arthur, 'Bai Bureh, the British, and the Hut Tax War', International Journal of African Historical Studies 7(1), 1974, 99-106, 104-5.

115 Fyfe, History, 432.
} 
chiefs. British district administrators expressed this process in racist terms as effects of their 'civilising mission', but they indeed had direct control over most of the Protectorate chiefs. Groups that had in a long process in the second half of the nineteenth century decided to define others as arch-enemies, now had to find ways to coexist within the new structures of 'indirect rule'. This evolution was in part mediated through the creation of Protectorate-wide structures: British authorities canalised the 'education' of both future chiefs, and of their councillors and clerks as in Senegal, through education facilities for the sons of chiefs who were obliged to use them, and later on, through the Bo School of Administration whose graduates developed their own corporate identities as 'old boys'.116

In spite of colonial taxation and forced labour, the colonial state in Sierra Leone had the paradoxical effect of allowing communities to live free from experiences of destruction and pillage, in relative safety. In isolated districts of the Sierra Leone Protectorate, British control was of course less immediate and European officials and merchants and Lebanese traders had to rely on porterage to distribute information and goods. Here, the power of local leaders was less controlled, as was the case in the district of Karene before the 1920s. ${ }^{117}$ Even for such remote regions, the existence of the urban centre of Freetown with its range of labour opportunities became a mighty attraction. What had slowly started before 1898 , soon expressed itself in a steady flow. ${ }^{118}$ Instead of refugee slaves, these immigrants were now mostly free labourers, although 'domestic slavery' remained a problem in Sierra Leone, as it was in early twentieth-century Senegambia. ${ }^{119}$ Subsequent provincial commissioners of the Northern Province claimed that the flight of slaves had become infrequent, and that many slaves had a strong preference for staying with their masters, thus explaining away the dilemma. However, in general, these reports were erroneous. The commissioners only repeated the opinion of the Temnespeaking paramount chiefs, and thus avoided the delicate task of interfering in master-slave relations. ${ }^{120}$

116 Corby, Richard A., 'Bo School and Its Graduates in Colonial Sierra Leone', Canadian Journal of African Studies 15(2), 1981, 323-3, 331-2.

117 TNA, PRO, CO/267/607, Lyon, District Commissioner of Karene District, Annual Report of the Karene District for 1924 (without number), 19 March 1925, 32-3.

118 Little, Mende, 24.

119 Rashid, Ismail, "'Do dady nor lef me make dem carry me": Slave resistance and emancipation in Sierra Leone, 1894-1928', Slavery \& Abolition 19(2), 1998, 208-31, 216-9.

120 TNA, Pro, CO/267/595, Stanley, Provincial Commissioner of the Northern Province in Mahump, [Report on the Northern Province] (without number), 12 April 1922, 10. 
The issue of slavery and the question of refugees moving into Freetown created a consensus amongst many of the local paramount chiefs, within and beyond the Temne-speaking area, who opposed any unilateral measures on the part of the colonial administration. The British government in Freetown regarded a unilateral decree of abolition as dangerous, as they argued that this could lead again to revolt and 'civil war', in the style of the Hut Tax War. However, many officials admitted that a large number of the slaves were less than content with their personal situation. ${ }^{121}$ The influx of refugees furthered the permanent presence of a rapidly increasing group of 'foreigners' in Freetown, who were important for processes of social change.

Freetown could indeed have been a large melting pot, where ethnic sentiment could have been fused into urban group identification. Allen M. Howard holds indeed that the colonial capital knew, in the first three decades after 1898 , several conflicts of a strongly social character that united inhabitants of different ethnic origins. ${ }^{122}$ Strikes and mobilisation against Lebanese merchants during the 1919 riots are typical of this form of social conflict. ${ }^{123}$ However, the British administration was active from the early twentieth century in countering these trends by the employment of principles of 'indirect rule'. To protect 'tribesmen' from 'detribalisation' in the population centre of Freetown, British officials now increasingly relied on the system of 'tribal rulers'. For the newly created Headquarters District, they now based selection processes for chiefs on what they believed were solid anthropological results. ${ }^{124}$ This new approach of searching for 'authentic chiefs' coincided, interestingly, with a second tendency that helped these rulers to build up a considerable authority. ${ }^{125}$ Both the Temne-speakers and the Mende-speakers of Freetown appear, in the 1920s, to have largely accepted the role of those suburban chiefs as their principal spokesmen. Individuals arriving in the urban agglomeration as refugee domestic slaves respected the prestige of the city's 'tribal chiefs'.

121 TNA, PRO, CO/267/604, Slater, Governor of Sierra Leone, Slavery: Reviews history of - in S.L. \& action taken to abolish it \& submits recommendations for accelerating the abolishment (without number), 20 June 1924, 4.

122 Howard, Allen M., 'Contesting Commercial Space in Freetown, 1860-1930: Traders, Merchants, and Officials', Canadian Journal of African Studies 37(2), 2003, 236-68, 261-2.

123 See, also, for the 1930s Abdullah, Ibrahim, "Liberty or Death": Working Class Agitation and the Labour Question in colonial Freetown, 1938-1939', International Review of Social History 40(2), 1995, 195-221.

124 Goerg, Odile, 'Chefs de quartier et 'Tribal Headmen': Deux visions des colonisés en ville', in Jean-Pierre Chrétien and Gérard Prunier (eds), Les ethnies ont une histoire (second edition, Paris: Karthala, 2003), 267-82, 272.

125 Northrup, 'Becoming', 12. 
This allegiance of Temne-speakers to the 'tribal ruler' in the urban agglomeration played a major role, although it would have been relatively easy for members of the group to leave the suburban areas where Temne-speaking immigrants normally settled. This occurred only rarely. ${ }^{126}$ The Temne community, having established itself during the course of the second half of the nineteenth century as the numerically strongest group in the urban area of the colonial capital, showed a remarkable degree of cohesion. ${ }^{127}$ Other communities, such as the Kru in Freetown who were a longer-established group of new settlers and quite numerous, were far more subject to internal struggles and challenged the chiefs installed by the colonial power. ${ }^{128}$

In the 1920s and 1930s, however, the importance of ethnic links became notably weaker, both in the urban environment and in the rural districts. In the Headquarters District, the Temne-speaking (and, also, the Limba-speaking) populations were slow to elect new, 'tribal' paramount chiefs after the deaths of the former post-holders. The British complained of a surprising lack of interest on the part of the communities. The post of 'Temne tribal ruler' was not filled for 22 months after the death of the old chief in November 1922. The Limba-speakers did not hold any election whatsoever after their 'tribal ruler's' death in $1923 .{ }^{129}$ Former attempts of Temne 'tribal rulers' to bring under their control the Limba community in the urban agglomeration were abandoned. 'Tribal' politics in the region of the capital slid into the background. ${ }^{130}$

In the rural constituencies of northern Sierra Leone, the reliance of groups both Temne-speakers and their Loko-speaking and Limba-speaking neighbours

126 TNA, PRo, CO/267/595, Annual Report on the Headquarters District 1921. (without number), without date, 2 .

127 Harrell-Bond, Barbara E.; Allen M. Howard, and David E. Skinner, Community Leadership and the Transformation of Freetown (1801-1976) (The Hague: Mouton, 1978), 77-9.

128 TNA, Pro, CO/267/595, Maxwell, Acting Governor of Sierra Leone, to Churchill, British Secretary of State for the Colonies ( $\left.\mathrm{n}^{\circ} 157\right), 18$ April 1922, 10; TNA, PRO, CO/267/595, 'Representatives of Kroomen in Freetown' to R.J. Wilkinson (without number), without date, 1, 4; TNA, PRO, CO/267/595, Delegates of Freetown's Kru Community to Maxwell (without number), without date, 1; Frost, Diane, Work and community among West African migrant workers since the nineteenth century (Liverpool: Liverpool University Press, 1999), 135 .

129 TNA, PRo, CO/267/607, James, District Commissioner of Headquarters District, Annual Report of the Headquarters District for the Year 1924 (without number), without date, 4.

130 Moseley, K.P., 'The Safroko Limba of Freetown, I: taingains time', Africana Research Bulletin (Fourah Bay, Sierra Leone) 15, 1985, 41-80. On abuses by Temne-speaking chiefs - in which ethnic allegiance did not play any role - see SLA, Box 698/3, Bai Maro Camarah and Folah Camarah, Mamara, Koya Chiefdom, Port Loko District, to Taylor, Acting District Commissioner of Port Loko (without number), 28 Jan. 1931, 1-2. 
- on ethnic formulae relaxed even earlier. This development was in fact a reverse trend to British colonial planning: the administration clearly wished to organise the inhabitants of the new districts according to an ethnic perspective. The British authorities, who, in the immediate aftermath of the Hut Tax War, had for a while concentrated on removing opponents and rewarding allies, tried to establish principles according to which the northern chiefs were reinvested with considerable power and influence. ${ }^{131}$ The organisation of local rule was expressed in ethnic terms. This had effects on the terminology used by local rulers in their dealings with the British Native Administration: in the different rural zones of Sierra Leone, 'strangers' coming from other regions were now normally described according to their ethnic affiliation. This became quickly visible in court records in all of the districts. ${ }^{132}$

In Karene District, the British district commissioner distinguished between four main groups in 1924, pointed out to him by the respective local auxiliaries of the administration. On the basis of such information, he categorised them as 'Limba', 'Susu', 'Loko', and 'Temne', referring thus to the pre-colonial labels. In his comments, however, the British official admitted that with reference to 'social customs and law', those groups were 'very similar'. He also described the two first and the two last as overlapping as to their political entities. With this comment, the colonial official merely generalised on military events of the late nineteenth century, as Limba-speakers of the district had been victims of aggressive incursions by Susu-speakers, and Loko-speakers had been attacked and enslaved by Temne-speakers. He insisted that the four groups were nevertheless clearly distinguishable, as their members discussed in oral accounts. In those accounts, language was the principal criterion of distinction: thereby, informants from all four groups insisted on their uniqueness in linguistic terms.

Much of 'Temne-ness' was defined by locals with reference to 'stranger' minority groups living in the district, such as 'Fulbe', 'Mandinka' or 'Koranko'. The members of such smaller communities were to be denied the right to selfrule: Temne-speaking informants argued that such 'foreigners' had never before had their own chiefs or political privileges. They were to be kept in 'benevolent' networks of patronage. ${ }^{133}$ As with the Laobe and Sarakole of

\footnotetext{
131 Dorjahn, Vernon R., 'The Changing Political System of the Temne', Africa (London) 30(2), 1960, 110-40, 114-5; Sibanda, 'Dependency', 488.

132 See tNA, PRo, CO/267/6oo, Bowden, Chief Commissioner of the Central Province, Enquiry into the Causes of Discontent in the Lunia Chiefdom (without number), 17 to $3^{1}$ August 1923, 33 .

133 TNA, PRo, CO/267/607, Lyon, Annual Report of the Karene District for 1924 (without number), 19 March 1925, 2-3.
} 
Senegambia, Temne-speaking chiefs and headmen attempted to minimise the political role of small groups, in order to enlarge their own constituencies.

While it seems obvious that self-perception on ethnic terms during the first thirty years of the Protectorate could have advantages, the principle actually lost some of its appeal, instead of, as propagated by the colonial power, becoming the decisive criterion of local organisation. During conflict-ridden chieftaincy successions in the north in the 1910s and 1920s, we find few attempts by local groups to take over chieftaincies through ethnic claims. Even in the cases of Upper Lokko or Sanda Chenraron, inhabited by a majority of Loko-speaking populations with a minority of Temne-speakers, the conflicts around the succession in those chieftaincies were remarkably free from ethnic propaganda. The respective claims of 'traditional families' were essential for the succession, and these claims mobilised both Temne-speaking and Loko-speaking electors. ${ }^{134}$

Just as in the south of Sierra Leone, where the identification as 'Mende' did not become the critical variable for some time, the north also did not obey ethnic principles. There was no policy of 'Temneisation' in the Northern Province. Even so, some conflicts re-emerged after a period of tranquillity: and it was indeed the members of smaller communities who claimed that they were being mistreated by Temne-speakers. In the 1920s, some protests occurred in different districts of the north, which became louder and deplored the fact that 'the Temne' attempted to marginalise other populations by dominating the chieftaincies. In Bombali, where Loko-speakers and Limbaspeakers defended a minority position in six of the 28 chiefdoms, they protested against attempts to impose on them a native authority dominated by Temne-speakers. The Limba and Loko populations of the six chieftaincies insisted that they should not be put under Temne majority rule. ${ }^{135}$ This aggressive rhetoric by Limba-speakers was, however, contradicted by internal conflicts of the Limba community. In Bombali District, the two Limba-speaking chiefs of Tamiso and Biriwa were caught in deep mutual hostility, and were thus unable to work together. During their struggles, the then Chief of Tamiso manipulated Limba-speaking populations in his chiefdom, in an attempt to bring the neighbouring Limba under his own control. ${ }^{136}$ This led to frictions and benefited the Temne-speaking chiefs in the district, who profited from

\footnotetext{
134 TNA, PRo, CO/267/607, Lyon, Annual Report of the Karene District for 1924 (without number), 19 March 1925, 12.

135 TNA, Pro, CO/267/595, Kemp, District Commissioner of Bombali, to Provincial Commissioner of the Northern Province (without number), , Feb. 1922, 1, 4.

136 TNA, PRo, CO/267/595, Annual Report 1921: Koinadugu District (without number), 8-9.
} 
the weakness of the Limba chiefs to enlarge their control over local populations. ${ }^{137}$

As regards the interwar period, the most important picture in the north is one of remarkable stability and absence of violence on ethnic terms. Several of the abuses that led to rural revolt in the 1950s already existed, but their existence was not linked to ethnically expressed conflict. In other words, in this phase of the colonial period, the trends towards ethnic polarisation that had become apparent in the wars of the late nineteenth century, were not yet transformed into long-lasting hostilities. All in all, rural Sierra Leoneans appear to have been very eager once again to lock the principle of ethnic identification in the closet, without any clear perspective that it would become useful in the future.

Ironically, during these years, it had the 'benign' effect that local paramount chiefs and their families were mostly detached from any political interest in Freetown, as the decline of Creole power had made obsolete any attempts by this group to enlarge their influence in the countryside. The racist assumptions of British officials effectively shut the chiefs out of political networks, except from their presence in Protectorate assemblies, where they sat, however, in a quite reduced number and amongst themselves, and united on collectively interesting issues, such as the above-mentioned problem of refugee slaves. The politicisation of first the urban agglomeration, and then the rural constituencies after 1945, entirely changed this picture. It drew Sierra Leone's north (and, indeed, other rural provinces) into a process in which ethnicity again became an emotive variable. ${ }^{138}$

\section{Polarised Democracy? The Creation of Electoral Bodies, Ethnic Mobilisation, and the Challenge of the Northern Chieftaincies, $1945^{-1961}$}

In the colonial territory of Sierra Leone, we first find violent protests against the authorities in the late 1920s and the 1930s. Those protests were initially an urban phenomenon mainly in Freetown and the Sierra Leone Peninsula. They were connected to economic decline in the context of the Great Depression, to falling wages of dock workers and urban personnel, and to the energetic activities of

\footnotetext{
137 Fanthorpe, Richard, 'Locating the Politics of a Sierra Leonean Chiefdom', Africa 68(4), $1998,558-84,568-70$.

138 Cartwright, Politics, 75-6.
} 
someleading personalities of the urban area, such as Isaac T.A. Wallace-Johnson. ${ }^{139}$ During these struggles - which were often interpreted by British authorities in the context of very diffuse anti-Communist fears - the 'northerners', and, more clearly, the 'Temne' in the Headquarters District, were regarded as conforming exactly to ethnic patterns: they seemed particularly loyal to their elected 'community leaders'.

After the Second World War, the northern parts of the Protectorate appeared to remain largely untouched by any conflicts between ethnic groups. Colonial officials believed that the slow material improvement of local societies would further weaken ethnic group sentiment. Kenneth Little, leading British sociologist of the Mende working in the late 1940s with the British government, commented that 'tribal affairs' would be of limited importance in the future. ${ }^{140}$ For the Temne-speaking parts of Sierra Leone, the late 1940s seemed to confirm these claims, as was argued in a detailed report on the social relations within the districts of the Northern Province. In Bombali District, Temne-speaking and Limba-speaking groups (the Biriwa Limba) were now said to live amicably side by side': reports pointed to a large number of intermarriages, and in the chiefdom of Mapaki, one paramount chief governed two linguistic 'sections' that were roughly equal in size. ${ }^{141}$ In Kambia District, the same was reported for Temne-speaking and Bullom-speaking populations, as the latter seemed practically absorbed into the larger group. ${ }^{142}$ However, further northwards, old fissures remained present. Susu-speakers did not mix with the Temne-speaking majority, reflecting old rivalries. In Sanda Loko, distinctions between Temnespeakers and Loko-speakers were alive in the institutional set-up: the paramount chief in the 1940 insisted on maintaining two different sections with their respective representatives. ${ }^{143}$ Fulbe pastoralists were regarded with suspicious glances by members of all the other communities in these northern districts, which in part reflected the past fears of invasion from the Fuuta

139 See Spitzer, Leo, and LaRay Denzer, 'I.T.A. Wallace-Johnson and the West African Youth League. Part II: The Sierra Leone Period, 1938-1945', International Journal of African Historical Studies 6(4), 1973, 565-601, 585 .

140 Little, Kenneth L., 'Social Change and Social Class in the Sierra Leone Protectorate', American Journal of Sociology 54(1), 1948, 10-21.

141 TNA, PRO, CO/1018/65, Cox, [Lord Hailey's Questionnaire], Bombali District (without number), without date [1948], 1 .

142 TNA, PRO, CO/1018/65, District Commissioner of Kambia, Kambia District (without number), without date.

143 TNA, PRO, CO/554/1993, David Edwards, Commissioner of Inquiry in Makeni, Report under Section 36(2) Protectorate Ordinance (Cap. 185): Sanda Loko Chiefdom - Paramount Chief Bai Samura (without number), 28 Jan. 1957, 1. 
Jallon. ${ }^{144}$ In some cases, cattle-breeders were forced to pay levies that were of doubtful legality or were even clearly illegal according to colonial law, on the grounds that they had to support financially the agricultural efforts of the Temnes' as the real 'natives'. ${ }^{145}$

Most important, however, was the renewed conflict between 'Temne' and 'Mende'. Bai Kobolo, interviewed by Lord Hailey in 1948 during the latter's stay in Freetown, argued that the fundamental differences between Temnespeakers and Mende-speakers were expressed in the organisation and the powers of the secret societies, the Poro: he claimed the Temne Poro were stronger and more authentic; he also held that among Temne-speakers, cultural homogeneity was strong, and far more important as a factor of allegiance than Islamic faith. This was a constructed opposition that had little to do with trends in political life. ${ }^{146}$ Still, in the Northern Province in the late 1940s, the incidence of group hostilities was at its lowest.

In 1948, the Temne-speakers tended to rely on the ruling dynasties for nominating successors, which reduced the number of effective conflicts. ${ }^{147}$ In most of the northern chiefdoms, the paramount chiefs ruled with their inner circles of trusted councillors rather than with the native authority. Most British officials believed that this state of things was, more or less grudgingly, accepted by the populations and by headmen who stood lower in the hierarchy, which preserved local peace in a principally illegal, but 'informally correct', manner. ${ }^{148}$ Only in the second half of the 1950s would those officials see their mistake.

The picture changed considerably during the 1950s. A number of increasingly violent rural revolts against local paramount chiefs hit different communities all over the Protectorate. While it is difficult to construct a political connection between such events - as opposed to the Senegambian case where one could point to the impact of party politics - the riots nonetheless amounted to a strong challenge to the prestige of 'traditional rulers' in general, with the northern areas also being increasingly affected. ${ }^{149}$

\footnotetext{
144 TNA, PRO, CO/1018/65, District Commissioner of Kambia, Kambia District (without number), without date, 4 .

145 TNA, PRo, CO/554/1993, Edwards, Report under Section 36(2) Protectorate Ordinance (Cap. 185): Gbanti Kamaranka Chiefdom - Paramount Chief Kande Ture III (without number), 28 Jan. 1957, 4.

146 TNA, Pro, CO/1018/65, Cox, Chief Bai Kobolo (without number), without date, 3.

147 TNA, PRo, CO/1018/65, Burns, Acting Provincial Commissioner, [Remarks to Lord Hailey's Questionnaire:] Northern Province - Makeni. 13th March. (without number), without date, 5.

148 TNA, PRo, CO/1018/65, Cox, [Lord Hailey's Questionnaire:] Port Loko District, Present D. Bayley, District Commissioner, Port Loko (without number), 12 March 1948, 1-2.

149 Tangri, Roger, 'Conflict and Violence in Contemporary Sierra Leone Chiefdoms', Journal of Modern African Studies 14(2), 1976, 311-21, passim.
} 
Anti-chieftaincy riots became typical for the whole of the Protectorate in the 1950 s. $^{150}$ Some of the formerly most prominent paramount chiefs thus came under serious pressure. The pressure groups included in some cases the 'native authorities', the councils of dignitaries elected according to 'customary rule': they used the tendency towards introducing voting rights for an all-Sierra Leonean Parliament to challenge the autocratic power of individual paramount chiefs. The protests targeted the exploitative ways in which these chiefs behaved. Over the course of the 1950s, as a result of the protests, a large number of Protectorate chiefs were implicated in trials for the overstepping and misuse of their administrative powers. ${ }^{151}$ In the north, out of the six most important paramount chieftaincies, at least four were under suspicion of serious abuse of power. Flexibility and improvisation now made it possible for contenders to present themselves, without relying on the strict rules often written down in the Government guidebooks of customary law. Remarkably, these processes were at first almost confined to the Mende-speaking south of the Protectorate, but from there they made themselves known further afield, with an impact in the Limba, Loko and Temne zones of the Northern Province. As will become clear from the four most violent and most exemplary cases of local unrest in late colonial Sierra Leone which were reported from regions all over the country, it is possible to identify a general pattern of protest, which, as we will see, was in its initial phase non-ethnic. This general pattern subsequently became a certain model for the events in Temne-speaking regions, and, therefore, it is necessary to discuss the territorial typology of events. Four particularly large scandals illustrate the initial similarities of protest all over the Protectorate, and it makes sense to have a look at them.

In Luawa in Kailahun District - a Mende-speaking region in the far southeast of the Protectorate - Paramount Chief Sama Kailundu Banya had reintroduced since the interwar period the ancient practice of Manje forced-labour farms. This practice had been an instrument for producing food for warfare, and had as such been omnipresent in southern Sierra Leone before 1898, but it had disappeared under British Protectorate rule. ${ }^{152}$ Manje practices were not automatically an abuse from the point of view of the local populations. Indeed,

$15^{0}$ Rashid, Ismail, 'Rebellious Subjects and Citizens: Writing Subalterns into the History of Sierra Leone', in Sylvia Ojukutu-Macauley and Ismail Rashid (eds.), The Paradoxes of History and Memory in Post-Colonial Sierra Leone (Plymouth: Lexington Books, 2013), 13-36, 29.

151 TNA, PRo, CO/554/1993, Dorman, Governor of Sierra Leone, to Eastwood, Assistant Under-Secretary at the Colonial Office (without number), 16 Feb. 1957, 1-2.

152 TNA, PRO, CO/267/701/1, Hancock, Provincial Commissioner of the Northern Province, Report on the Evidence on Charge 1 against Paramount Chief S.K. Banya (without number), 9 July 1950, 1. 
when Banya had started with these practices, he had behaved according to the expectations and with the encouragement of the nobles of his chieftaincy. As he had obtained the chieftaincy at quite a young age, and had thus started with a rather weak standing, the headmen had advised him to strengthen his authority by creating such Manje farms. ${ }^{153}$ This plan went undeniably wrong. When Banya had become an established ruler, with a secured authority, he became more demanding towards the labourers, and used them openly for his own private profit. Contrary to the former practice that had conformed to local usages, this was no longer tolerable from the point of view of the headmen. The latter in the end agreed to mobilise the populations through the Native Authority, and in consequence expelled the paramount chief from Kailahun. ${ }^{154}$

Baoma in Bo District in the South-western Province, a mixed Mendespeaking region, was a similar case. Here, the three 'ruling houses' of the Kondor, Kragbate, and Demby had competed for the chieftaincy during the whole of the colonial period. ${ }^{155}$ Alfred C. Demby's coming to power in 1912 had found the support of the headmen. Afterwards, Demby had pursued the nomination of his own appointees to the Tribal Authority, but this was a rather 'normal' practice, and had thus not caused any protest from the populations. However, when the paramount chief overstepped his rights and privileges, these abuses aroused a storm of protest. In the event, Demby attempted to force his subjects into unpaid road labour - reviving a practice that the colonial power had tacitly banned after the Second World War. He also directed a rather large state payment for rice exportations from his chiefdom into his own pocket. ${ }^{156}$

In this particular case, the Tribal Authority was passive - which is not surprising because it consisted mainly of Demby's followers and clients. Nevertheless, local populations were organised enough to help themselves out of this situation. In 1949, the opponents of Demby's rule created a protest

153 TNA, PRO, CO/267/701/1, Bang, Nassama, Morikku, Assessors of Enquiry against Sama Kailundu Banya, Report of the Assessor Chiefs on the Commissioner's Report (without number), 11 July 1950.

154 TNA, PRO, CO/267/701/1, Bluk, P.C. Sama Kailundu Banya (without number), 16 Oct. 1950; SLA, Box 567, Waldock, Acting Commissioner of the Southeastern Province to Hancock, Acting Chief Commissioner of the Protectorate at Bo, Disturbances at Luawa. (without number), 30 Oct. 1950, 1; SLA, Box 567, Hancock to Colonial Secretary at Freetown, Luawa Chiefdom. ( ${ }^{\circ}$ C.C.P.1346), 9 Nov. 1950.

155 TNA, PRo, CO/267/701/8, Weir, Baoma Chiefdom Disturbances, November 1948: Report of Commission of Inquiry (without number), $3^{1}$ Oct. 1949, 5-7.

156 TNA, PRO, CO/267/701/7, Beresford-Stooke to Griffiths (n ${ }^{\circ} 76 / 7069 / 12$ (T.S.)/CONF.), 22 April 1950, 1, 3. 
movement that became, over the weeks and months, increasingly violent. The activities of this movement forced the chief into exile, and persuaded the British administration to agree to the nomination of another, allegedly more popular candidate. Nonetheless, the members of the protest movement respected the ancient rights of the 'traditional' ruling houses, and, significantly, they chose the new candidate from the ranks of these houses. ${ }^{157}$

In Soro in the Pujehun District of South-western Province - a Mendespeaking region - we have all the typical components of forced labour abuses and exploitation, which united to give rise to the violent protests of local populations. The paramount chief, Mana Luseni, had had a ruling strategy different from that of Sama Kailunda Banya, or Alfred Demby: he relied on a violent group of supporters. The strength from this support also allowed him for a time to exact forced labour to have his own land cultivated, which was not only against the colonial legislation, but violated the 'Mende Customary Laws' that the colonial power had codified in the 1930s. ${ }^{158}$

Luseni soon went too far. In consequence, a coalition emerged against him amongst the Native Authority headmen, who called upon the local populations to expel their ruler from the chiefdom. Luseni saw the signs and simply chose not to return from one of his prolonged stays outside of the province, choosing exile to avoid physical attacks. Even in his absence, however, the memory of Luseni's particular brutality was enough to provoke an especially violent aftermath. After it became obvious that the chief had fled the region, the local people destroyed the houses of the former ruling family, to symbolically punish the Luseni dynasty for the old chief's behaviour. ${ }^{159}$

Finally, in Kaiyamba chiefdom in Moyamba District - a Mende-speaking region, but with a strong Temne-speaking minority - violent clashes were motivated by a succession conflict. In 1951, this conflict was triggered by debates about the right of Ella Koblo Gulama, daughter of the deceased chief

157 TNA, PRo, CO/267/701/8, Weir, Baoma Chiefdom Disturbances, November 1948: Report of Commission of Inquiry (without number), 31 Oct. 1949, 35; SLA, Box 567, D.L.G. Gbenga, Secretary of the 'Political Honours Scrutiny Committee', Bo, to Governor of Sierra Leone (without number), 4 June 1950; SLA, Box 567, Tommy Tendia, Amara Saowa, Alpha Kondoh, 'Members of the Opposition Party, Baoma Chiefdom' to 'the Organising Secretary' of the West African Youth League (without number), 27 June 1950, 1.

158 TNA, PRo, CO/554/704, Beresford-Stooke to Lyttelton, British Secretary of State for the Colonies (n 193/S.L.M.P./11216), 13 Nov. 1951, 1; TNA, Pro, CO/554/704, Childs, Chief Commissioner, Southwestern Province, Bo, to Lyttelton, Paramount Chief Mana Luseni (n ${ }^{\circ}$ 1361/50/C.C.P.), 29 Oct. 1951 (Appendix).

159 TNA, Pro, CO/554/704, Osborne, Head of West African Department, Colonial Office, [Comment] ( ${ }^{\circ}$ 193), 13 Sep. 1951. 
Julius Gulama, to herself become chief of Kaiyamba. The headmen in the Native Authority had decided in her favour, obviously respecting the prestige of the ruling family and its eventual right to nominate a successor. ${ }^{160} \mathrm{~A}$ minority of those headmen complained, however, that the election was unfair, as Julius Gulama had installed his own favourites in the local institutions. The beginnings of differentiation on ethnic terms were a part of these complaints: Gulama's opponents argued that the old chief had ruled with the particular support of Temne 'strangers', and pointed to the fact that his daughter was married to an influential Temne-speaker which was perceived as treason. ${ }^{161}$ The discussions first resulted in a political deadlock, then in major disturbances all over the region of Kaiyamba. The result of the dispute was that Ella Kobolo took the chieftaincy in 1952, but the local community remained bitterly divided over this question.

Thus, in all four cases - and in several others that did not reach such a violent stage - the conflicts in the hinterland of Sierra Leone were not a revolt against outmoded 'traditional rule'. They were, on the contrary, part of a process of renegotiating and redefining how chieftaincy ideally had to function. Protesters and rioters in rural Sierra Leone demanded that the behaviour of chiefs had to be more sensitive to the clear interests of the local populations. The targets of revolt (where it happened) were, at first, those who had committed the most blatant abuses; they suffered violent, vengeful reactions. Chieftaincies were prestigious enough to attract new contenders who wished to profit from the outrages committed by the former title-holders. In the case of the well-respected Sierra-Leonean chiefdoms, many rival candidates appeared; however, they were normally members of a maximum of three or four eligible houses and there was less space for outsiders. British colonial policy in the 1950s had difficulties in coping with such tensions, and administrators oscillated between, on the one hand, the idea of supporting 'democracy' under all circumstances, and, on the other hand, the need for good cooperation with long-standing rulers. The emergence and evolution of political parties only complicated this picture. The British authorities agreed to the position formulated in London that it was useful to work increasingly through well-educated and elected representatives of the local populations and the Executive Council

16o TNA, PRO, CO/554/710, Rowland to Williamson, official of the West African Department, Colonial Office (without number), 15 Sep. 1952.

161 TNA, PRO, CO/554/710, Sandercock, District Commissioner of Moyamba, to Childs (without number), 22 Sep. 1952. On the career of Ella Koblo Gulama, see, also, Lucan, Talabi Aisie, The Life and Times of Paramount Chief Madam Ella Koblo Gulama (Freetown: PenPoint Publishers, 2004). 
in the colonial capital, and they promoted networks between the 'ministers' in council in Freetown and local clients. ${ }^{162}$

This allowed the same ministers to create for themselves a following of chiefs or to introduce chiefs into their own parties, which is also typical of the situation in Senegambia, and, amongst multiple approaches, in the TransVolta area. The second objective of the colonial state, namely to create a good and 'fairly democratic' everyday policy in the chiefdoms, remained weak, however. ${ }^{163}$ British administrators in the end focused on guaranteeing a relatively smooth transfer of power at the level of the central government. The fact that violence in the 1950s never seemed to represent an attack against the colonial power seemed to be reassuring. ${ }^{164}$ Also, at the start of the 1950s, while British officials had rapidly understood that chieftaincy continued to matter, they did not comprehend in which sense the continuing role of the chiefs would function, and the party leaders in Freetown were unable to explain to the British the basic reasons for rural conflict. As the representatives of the colonial power did not want to 'overcharge' themselves with too many inquiries regarding those issues, they rather decided not to interfere in the hope that they would finally grind to a halt. ${ }^{165}$

Such a strategy of non-intervention and putting off taking action regarding the conflicts around local power till a future time, was difficult to maintain. Party politics lurked everywhere, as the leaders of the newly formed political movements in Sierra Leone were extremely active in creating themselves an appropriate following. ${ }^{166}$ Therefore, in the violent dispute about the Kaiyamba chieftaincy, Milton Margai and Siaka Stevens, the leading politicians in the new representative structures in Sierra Leone, each supported a different

162 TNA, PRO, CO/554/710, Beresford-Stooke to Lyttelton, Negotiations between the Government of Sierra Leone and the Sierra Leone Selection Trust ( ${ }^{\circ}$ 1088), 29 Oct. 1953.

163 On the inherent contradictions, see TNA, PRO, CO/554/710, Wallace-Johnson, SecretaryGeneral of the West African Liberties and National Defence League and West African Youth League (Sierra Leone Section) to Colonial Secretary of Sierra Leone (without number), 27 Aug. 1952.

164 TNA, PRO, CO/267/701/4, Beresford-Stooke, Extract from Letter from Governor, Sierra Leone, to Mr. L.H. Gorsuch, dated 22nd January, 1951 (without number), without date.

165 TNA, PRO, CO/554/710, Extract from a letter from the Governor of Sierra Leone to Mr. W.L. Gorell Barnes dated 21st January, 1953 (Orig. in WAf 62/4/02) (without number), without date.

166 Fred Hayward rightly argued that both Milton Margai and the leaders of the movement later transforming itself into the APC, did not play the ethnic card from the outset, see Hayward, Fred M., 'Political Leadership, Power, and the State: Generalizations from the Case of Sierra Leone', African Studies Review 27(3), 1984, 19-39, 22-3. 
candidate. ${ }^{167}$ This meant that both Ella Gulama and her main opponent, Lamina Kpangbavi, obtained help through unofficial channels and sought political patrons. Leading members of the Sierra Leone People's Party particularly set the tune in 'Mendeland', their home region, where they now also began to intervene in chieftaincy issues in favour of family members. In the most famous case, in the chiefdom of Imperi in November 1960, Hjabu Sei Kenja, the wife of the Prime Minister, secured for herself the paramount chieftaincy with the support of the SLPP machine. ${ }^{168}$

The experiences of 'Mendeland' constituted a general trend for the whole of the Sierra Leone Protectorate. As C. Magbaily Fyle rightly points out, chiefs were, from the 1950s, put in place by different political patrons. Nonetheless, Fyle is mistaken in claiming that those political measures 'distort traditions'. 169 On the contrary, the battle for rulerships had been similarly flexible in the nineteenth century, as had been the tactics of ethnic affiliation. Only from the perspective of the colonial power did those problems now emerge at the forefront of consciousness, particularly because the British administration had planned to finish with the power of the paramount chiefs and to come to 'modern forms' of government. In Sierra Leone's Northern Province, both objectives were seriously challenged.

I have discussed the broader panorama of the spectacular cases of 'chieftaincy troubles' in Sierra Leone in such detail, because we need to interpret the events in the Northern Province through this prism. In the first weeks of 1957, the tide of anti-chieftaincy riots reached a first spectacular climax in this province. The immediate cause was the misdeeds of the paramount chief of Safroko Limba, Almami Dura II, a Limba-speaking ruler. Dura was a central figure of local relations in the north: he was president of the Bombali District Council and a staunch SLPP supporter. He was part of a patronage network of paramount chiefs and sub-chiefs in the region, and enjoyed high prestige among his group of peers, who contributed a large number of presents on the occasion

167 TNA, PRO, CO/554/710, Rowland to Williamson (orig. WAF/C.66), 4 Oct. 1952, 2; TNA, PRO, $\mathrm{CO} / 554 / 710$, M.S. Turay, George Kebby, and others to Colonial Secretary of Sierra Leone, Re the Appointment of two Assessor Chiefs to go into and examine the Constitutional set-up that is, to verify the credentials and appointment of existing members of the Kaiyamba Tribal Authority (without number), 27 Aug. 1952, 1.

168 TNA, PRO, CO/554/2363, Telegram from Dorman, Governor of Sierra Leone, to Macleod, Secretary of State for the Colonies, Imperri Chiefdom Election $\left(\mathrm{n}^{\circ}\right.$ 92/1/019/1), 27 Jan. 1961; TNA, PRO, CO/554/2363, Sierra Leone (without number), without date.

169 Fyle, C. Magbaily, 'Oral Tradition and Sierra Leone History', History in Africa 12, 1985, $65^{-}-72,67$. 
of his installation to the presidency. ${ }^{170}$ In 1956, this reputation among fellow paramount chiefs was still unspoilt - but clearly this was no longer the case amongst local populations.

Regarding this context, we know Dura's own point of view in detail, and it is obvious that the changes in the attitudes of his subjects were, for him, entirely inexplicable: he believed himself to be behaving in 'traditional' ways. Dura claimed he had 'always' organised 'traditional' labour services, and did not understand why this was now to become a problem. ${ }^{171}$ However, the Temnespeaking spokesman of the Tribal Authority, Samba Koromah, sent the district commissioner details of an overwhelming number of abuses - forced labour and illegal levies - which are in fact representative of the general situation in the north:

That the Chief caused unpaid Labour to be used for his farms of both land and swamp and those of some of his Chiefdom officers. He even used forced Labour on Children under age (both male and female) even without food and without any pay. More aggravating was his practice of sending people to imprisonment [sic] for failing to do the work. They remained in prison until they paid whatever fines he further imposed.

A levy was forced from us for the purpose of buying himself a car he later disposed of, to Sahid Mohamed, Syrian Trader, Makeni. Another levy was imposed on us for the purchase of a lorry for him which was also disposed of, to late Paramount Chief Alimamy Kalawa of Bumban, Biriwa Chiefdom. Another levy for a purchase of a Humber car costing £1,200 one thousand two hundred pounds was imposed on us; and this car was disposed of, to Mr. R.C. Metzger, Motor Fitter, Makeni. A further levy was again imposed on us for the purchase of another car which [he] in turn disposed of, to Mr. J.M. Gbakiwa, Secretary, Bombali District Council, Makeni. Another levy still was imposed on us for the purchase of a car

170 TNA, PRo, CO/554/1993, Edwards, Report under Section 36(2) Protectorate Ordinance (Cap. 185): Bombali Sebora Chiefdom - Paramount Chief Bai Sebora Kamal II - Alhaji Kamara (without number), 29 Jan. 1957, 3; TNA, PRO, CO/554/1993, Edwards, Report under Section 36 (2) Protectorate Ordinance (Cap. 185): Gbanti Kamaranka Chiefdom - Paramount Chief Kande Ture III (without number), 28 Jan. 1957, 1.

171 Dura's networks with Lebanese merchants, combined with his engagement to appear as a pious Muslim, brought him the invitation to travel to Lebanon in 1952. See CADN, Fonds 'Anciennes Colonies', Fonds Dakar, 374, Bureau d'Etudes of the Government-General of French West Africa, Dakar, Sierra Leone: Un Paramount Chief invité à se rendre au Liban.$\left(n^{\circ} 611\right), 21$ June $195^{2}$. 
whilst he visited the United Kingdom; this car he used was costing $£_{1,700 \text {, }}$ now also disposed of, to Mr. Berthan Macauley, a Barrister in Freetown. ${ }^{172}$

His extravagant lifestyle had allowed Dura to create a network of supporters but in the 1950s this was no longer tolerated by the locals. His abuses led to serious riots. As a result of the protests, Dura was swiftly removed by the British administration. This interplay between violent challenges and British removals of chiefs became a familiar pattern in the Northern Province. ${ }^{173}$ Currently, we only have a small number of documents on these events in Sierra Leone's Northern Province in the former National Archives, and the civil war has made memories of the late colonial phase in this particular region highly unreliable. It therefore makes sense to view these repeated events through the available data from the commissions of inquiry. Herbert Cox, a former Gold Coast Provincial Commissioner, was the first of a group of British officials who reported information from the chiefdoms. The ethnic dimension remained notably absent from the actual group relations reflected in this testimony, while social conflict was very much commented upon.

In most cases, practices of forced labour were the central issue of the riots. In Marampa Masimera, the second speaker of the chiefdom, Yamba Bia, had organised compulsory labour on his land, with the agreement of the paramount chief, Bai Koblo Patbana. 'Illegal fines' were less important in the case of Marampa, as such fines appear to have been organised with the active help of many of the section chiefs, who now reappeared as plaintiffs. ${ }^{174}$ In Samu, where Temne-speakers had eclipsed the Bullom-speakers over the decades, the main argument in interpreting local riots was the rivalry between two local families. The Yek family, excluded from the paramount chieftaincy, was behind many of the local confrontations: a strike movement they organised against the labour policy of the paramount chief 'degenerated' into widespread violence, during which a number of police constables were killed. ${ }^{175}$

172 TNA, PRO, CO/554/1993, Samba M. Koromah, spokesman of the Native Authority of Safroko Limba, to District Commissioner of Bombali (without number), 25 Feb. 1957, 2.

173 See Moseley, K.P., 'Land, labour and migration: the Safroko Limba case', Africana Research Bulletin (Fourah Bay, Sierra Leone) 7, 1979, 14-44.

174 TNA, PRo, CO/554/1993, Harold Willan, Commissioner of Inquiry, Report under Section 36(2) Protectorate Ordinance (Cap. 185): Marampa Masimera Chiefdom - Bai Koblo Pathbana; Alimamy Sheriff - First Speaker; Yamba Bia-Second Speaker (without number), 19 Dec. 1956, 2-3.

175 TNA, PRo, CO/554/1993, Paul Storr, Special Commissioner in Kambia, Samu Chiefdom Paramount Chief Bai Sherbro Yumkella II (without number), 23 Nov. 1956, 1, 3; TNA, PRO, CO/554/1995, Godden, Summary for position in Samu Chiefdom (without number), without 
In Makeni, the question of abuses was less acute: Paramount Chief Bai Sebora Kamal II employed a 'regionalist' strategy that concentrated taxes on 'strangers', thus provoking criticism from the British officials. Local santigis (sub-chiefs) were, nonetheless, quite annoyed about the autocratic style of this Temne-speaking ruler, who had, in spite of being an 'educated' ex-employee of the United Africa Company - a large retail company belonging to Unilever not had the necessary tact towards his subjects and had apparently insulted the different representatives of the local authority. ${ }^{176}$ Kande Ture, the paramount chief of Gbanti Kamaranka, had also practised strategies of exclusion and of financial exploitation of 'strangers', particularly targeting the Fulfuldespeaking herdsmen. However, he had also demanded unpaid labour on his farms from the Temne-speakers, and by 1955 this led to widespread riots. ${ }^{177}$

In Sanda Loko, as regards which area I have already pointed to the more strongly 'ethnic' style of local organisation, Paramount Chief Bai Samura was accused of having demanded illegal fines, and of staffing his own farm in Makoli with involuntary labourers, abusing the institution of 'chiefdom labour', a type of 'traditional' regional labour tax. The commissioner saw the findings of the Cox Report as a plot. Even so, Bai Samura was removed as a consequence of the protests. ${ }^{178}$ In Loko Masama, the issue was again forced labour, with Paramount Chief Bai Sama exonerated by the commissioner of inquiry on the grounds that he had long been in his post, and had been used to employing compulsory labour on his farms. ${ }^{179}$ The situation was similar in Buya Romende, where Bai Banta Bento admitted the recourse to forced labour on eight plantations, but was also accused of confiscation of land and of having beaten a local headman. In Mambolo, accusations were similar. ${ }^{180}$

date; TNA, PRO, CO/554/1995, Telegram from Provincial Commissioner of the Northern Province, to Lennox-Boyd, British Secretary of State for the Colonies ( $\left.{ }^{\circ}{ }^{\circ} 16\right), 15$ Jan. 1957.

176 TNA, PRo, CO/554/1993, David Edwards, Commissioner of Inquiry in Makeni, Report under Section 36(2) Protectorate Ordinance (Cap. 185): Bombali Sebora Chiefdom Paramount Chief Bai Sebora Kamal II - Alhaji Kamara (without number), 29 Jan. 1957, 3.

177 TNA, PRo, CO/554/1993, Edwards, Report under Section 36(2) Protectorate Ordinance (Cap. 185): Gbanti Kamaranka Chiefdom - Paramount Chief Kande Ture III (without number), 28 Jan. 1957, 2, 4 .

178 TNA, PRo, CO/554/1993, Edwards, Report under Section 36(2) Protectorate Ordinance (Cap. 185): Sanda Loko Chiefdom - Paramount Chief Bai Samura (without number), 28 Jan. 1957, 2-6.

179 tNA, Pro, CO/554/1993, Willan, Report under Section 36(2) Protectorate Ordinance (Cap. 185): Loko Massama Chiefdom - P.C. Bai Sama - Alimamy Koroma - Alimamy Kamara (without number), 25 Nov. 1956, 6.

180 tNA, Pro, CO/554/1993, Willan, Report under Section 36(2) Protectorate Ordinance (Cap. 185): Buya Romende Chiefdom - Bai Banta Bento (without number), 6 Dec. 1956, 3-4; TNA, 
In Malal, the chief and his speakers had enforced involuntary labour on the roads and confiscated part of the rice harvests. ${ }^{181}$ Among the Yoni, 'traditional labour' was institutionalised in the form of a labour tax of two days of work payable to the paramount chief. Moreover, the Yoni chief, Bai Sherbro III, took immense fees through the local branch of the Poro Society, and brutally punished critics among the local headmen. ${ }^{182}$ Most shocking, however, from the point of view of the colonial government, was the evidence given by Bai Farima Tass II of Magbema, ruling over the Temne-speakers of Kambia and its surrounding region. The paramount chief, conversing in fluent English with the commissioners of inquiry, being a Minister without Portfolio in Milton Margai's government, and whose eldest son was living as a law student in the United Kingdom, was nonetheless convicted of practising extensive forced labour on his farms. ${ }^{183}$

Thus, in Port Loko and other districts of the Northern Province, Temnespeakers discussed widespread abuses, with forced labour being at the centre of the conflicts. British officials still believed they could, with an energetic approach of removing all those that stood in the way of good government, reestablish both the prestige of chieftaincy as an institution, and of the (slowly Africanised) administrative organisation. ${ }^{184}$ The British did not expect that at this point, ethnic interpretations would come back into play.

Like elsewhere in West Africa where chiefs had come under attack in the late 1940 s and the 1950s - I have already pointed to similar processes in Senegal tensions seemed to have social motives and little significance in ethnic terms.

Pro, CO/554/1993, Willan, Report under Section 36(2) Protectorate Ordinance (Cap. 185): Mambolo Chiefdom - Paramount Chief Bai Sherbro Woni Kebir II - Pa Kumrabai (without number), 18 Jan. 1957, 3 .

181 TNA, PRo, CO/554/1993, Edwards, Report under Section 36(2) Protectorate Ordinance (Cap. 185): Malal Chiefdom - Paramount Chief Bai Bairoh and Alimami Koroma (Speaker of Manewa) (without number), 28 Jan. 1957, 2-4.

182 TNA, PRo, CO/554/1993, Edwards, Report under Section 36(2) the Protectorate Ordinance (Cap. 185): Yoni Chiefdom - Paramount Chief Bai Sherbro III (without number), 28 Jan. 1957, 4-6.

183 TNA, PRo, CO/554/1993, Willan, Report under Section 36(2) Protectorate Ordinance (Cap. 185): Magbema Chiefdom - Paramount Chief Bai Farima Tass II. - Alimami Morifoday Alimamy Kamara (without number), 13 Jan. 1957, 2-4, 7-8. On the situation in Kambia District, see also SLA, Box 576, Commissioner of the Northern Province to Chief Commissioner of the Sierra Leone Protectorate, Tonko Limba Chiefdom - Kambia District $\left(\mathrm{n}^{\circ}\right.$ C.F.498/10), 6 Sep. 1957, passim.

184 TNA, PRo, CO/554/1993, Telegram from Dorman to Eastwood (without number), 19 Feb. $1957,1-2$. 
In Sierra Leone's Northern Province, the ethnic point of view appeared even less important than in the struggle between Sereer-speakers and Wolofspeakers on the Petite Côte: a chief like Dura II might have favoured Limbaspeaking partners, such as the chief Kalawa of Biriwa Chiefdom, but his network included a large number of Temne-speakers. Even so, we find a rapid evolution from challenges against chiefs who had ultimately wished to present themselves as 'tribal leaders' to a renaissance of ethnic thinking, which was then reflected in voting behaviour in the new Sierra Leonean institutions.

In the second half of the 1950s, the leaders of the SLPP and the future APC almost simultaneously changed their political strategy. The future APC politicians decided they were marginalised in the political institutions, and felt that a programme mainly appealing to the northerners, as distinct from, in particular, Mende-speakers, could turn the tide. At first, voters did not respond to the use of ethnic formulae. However, when Siaka Stevens became more aggressive in his tone, claiming that the Northern Province and, more directly, the Temnespeakers were excluded from both appropriate political representation and from the benefits of late colonial investment, the argument began to have more effect. The Margai brothers and other SLPP leaders, noticing that the north had increasingly become a difficult terrain for their electoral campaigns, focused more strongly on securing the entirety of the Mende-speakers as a reliable support base. ${ }^{185}$

However, while slowly ethnicising their campaigns, politicians from both parties remained eager to maintain in their camp at least some prominent support from the respectively opposing geographical region. Therefore, the Margais were active in courting a number of prominent Temne-speaking chiefs, even giving them government posts (although rather marginal ones). These chiefs now profited from SLPP protection when their abuses were related to the British governor in the late 1950s. This explicitly linked the interests of 'traditional' authorities and of ethnicised party politics for the last years of the colonial state. Not all of the paramount chiefs stood against a homogeneous opposition; in the case of Samu, the chiefdom was divided between the adherents of two families fighting each other, although belonging to one dynasty. ${ }^{186}$ In other cases, however, the resistance movement was far more violent.

The patronage of the autonomous government of the two prominent paramount chiefs, Bai Farima Tass II of Magbema and Alkali Modu of Maforki, led to a chain reaction. In view of various abuses, the British governor nonetheless

\footnotetext{
185 Wyse, Bankole-Bright, 164-78.

186 Minikin, Victor, 'Indirect Political Participation in Two Sierra Leone Chiefdoms', Journal of Modern African Studies 11(1), 1973, 129-35, 130-2.
} 
vacillated considerably in removing them from their positions. In 1957, these two had remained the only prominent Temne in Margai's leading and Britishsupported SLPP. ${ }^{187}$ Such hesitations created fresh outbursts of anger among the Temne-speaking populations: local headmen interpreted the SLPP as a party of 'southerners' merely wanting to keep its two remaining clients in the north in their positions, supporting corrupt structures and exploitation.

Finally, the two chiefs in question stepped down, but the reputation of the SLPP government in Sierra Leone's Northern Province was entirely ruined. The perception that the SLPP wanted to aid corrupt allies at the expense of the interests of the region's inhabitants was widespread. In the following five years, this experience made the Temne-speakers in the north very hostile towards politics formulated in Freetown. ${ }^{188}$ It was an easy task for Siaka Stevens and the other opposition leaders to convince the local populations that abuses in the north were the fruit of a 'Mende' conspiracy. Only then, and because of a conflict that involved the modes of chieftaincy in general far more than any ethnic dimension, did the latter criterion again enter Sierra Leonean politics, through the back door.

The documentation of the 1950 os leaves no doubt about the fact that the battles over chieftaincy were decisive in the process of ethnicisation. The affairs of Kaiyamba and elsewhere in Sierra Leone's south - the former involving Temne-speaking chiefs - had expressed a general feeling: chiefs were to be reminded that they had to work 'for the common good':

The time when Chiefs were looked upon as Gods is past. It is the duty of the Tribal Authority to advise the Chief, particularly a young Chief, when they see he is going astray. Should he not heed to their advice, worse still should he fine someone for giving such advice, they ought to report him to the District Commissioner, who, undoubtedly, would at most give him a warning for the first time. The Tribal Authorities have a duty to perform, and they should not fear to do so, or else the Chiefdom is bound to go wrong. ${ }^{189}$

The late colonial state was unable to react to these changes. Such passivity allowed politicians in Freetown to integrate the 'traditional structures' into their own networks of patronage: those structures would easily survive well

\footnotetext{
187 TNA, PRO, CO/554/1993, Dorman to Eastwood (without number), 16 Feb. 1957, 2.

188 TNA, PRO, CO/554/1993, Godden to Bennett, Assistant Secretary of West African Department, Colonial Office, and Eastwood (without number), 26 Feb. 1957, 2.

189 TNA, PRO, CO/267/701/1, Bang; Nassama; Morikku, Report (without number), 11 July 1950.
} 
into the post-colonial state. However, locals in the north began to interpret the shortcomings of both the colonial administration, and, in particular, of the SLPP government in punishing abusive chiefs as the result of an ethnic conspiracy. ${ }^{190}$

The political realities were complemented by particular patterns of migratory behaviour, which differed strongly from the more relaxed situation of the interwar period. During the 1950s, migratory movements in rural areas had taken forms that tended to reinforce the self-perception of groups as ethnic blocks. Vernon Dorjahn has shown, for the example of Kolifa Mayoso, that between 1955 and 1963 the rate of immigration from other, 'non-Temne' chiefdoms became extremely low, while 'Temne' migrated increasingly either into Temne-speaking towns, or into the Temne-speaking immigrant settlements of the Sierra Leone Peninsula. ${ }^{191}$ With the transition into the post-colonial state, such forms of closing ranks translated themselves into a clear allegiance to a regional and ethnic pro-Temne party, the APC - and made Siaka Stevens's takeover of political power and the end of the Sierra Leonean democracy possible.

\section{Through the Conjuncture of Ethnic Mobilisation and 'Peaceful Coexistence': Port Loko as a Crossroads in Northern Sierra Leone}

At the moment of the arrival of European administrators and black settlers on the Sierra Leone peninsula, Port Loko was already a significant commercial and political centre. In a strategically important position at an easily accessible creek, this city had control of a considerable hinterland. ${ }^{192}$ The rulers of Port Loko underlined this claim through the raising of tribute in smaller villages, where they regularly appeared. ${ }^{193}$ Superficial Islamic proselytisation had given these rulers the title of 'Alkali', and a certain prestige as protectors of the Muslim faith. Nevertheless, CMs missionaries quickly described the town as a particularly promising base for Christianisation in the region. This subsequently led to an early European presence in the settlement - and to European source material on Port Loko's political situation. Freetown Creoles coming as

\footnotetext{
190 Allen, 'Politics', 308.

191 Dorjahn, 'Migration', 34.

192 Howard, Allen M., and David Skinner, 'Network Building and Political Power in Northwestern Sierra Leone, 180o-65', Africa 54(2), 1984, 2-28, 10-7.

193 CMS, CA1/o 6o/55, Burtchaell, A day's itinerancy in the Temne Country Port Loko to Romanka (without number), without date [1879], 2.
} 
merchants and British diplomats also felt attracted by the strategic position of the town. In the nineteenth century, when Port Loko for the first time transformed itself into an ostensibly Temne settlement, these exchanges reflected a stronger ethnic identification.

When the British established themselves on the Sierra Leone Peninsula, Port Loko was all but an exclusively Temne-speaking community. In the town and hinterland, Mōri Burēma, a Susu-speaking ruler and successful Muslim war leader of the Sanko family, had established his own stronghold in the early 180os. ${ }^{194}$ The extension of his power at first went unnoticed by the British whose had at that time been absorbed by warfare against settlements in Koya and by their subsequent diplomatic efforts in Morea. In the first decade of the century, they seem to have largely ignored the importance of the neighbouring town. When the British started to become more active in the area of Port Loko, Mōri Burēma had already fortified his position in the port centre and challenged British control over the region. One of Burēma's major sources of income (running counter to British goals since the Abolition of 1807) was his major involvement in the sale of war captives. For this particular reason, British authorities in Freetown oscillated between the attempt to establish good relations with the ruler and support for his adversaries.

British observers unanimously believed throughout the decade that Burēma was a 'stranger' and, as such, a usurper. However, it is obvious that in the period around 1810, Burēma was popular with at least a section of the local political hierarchy. He had originally come from a Mandinka-speaking settlement further northwards, and had brought with him a warrior band, whose military force had helped him to secure control over the town. Subsequently, he played in part the card of ethnic affiliation by concentrating his Mandinka followers in the newly-built town centre of Romakbum outside of the fortifications of Port Loko. This policy provoked some resistance. ${ }^{195}$ However, Burēma courted several of the local Temne-speaking chiefs to stabilise his rule, and they proved to be reliable partners during a whole decade. He masterfully played the card of group identifications whenever it suited him, although in this respect the British reports from Freetown are full of exaggerations, as British officials regarded the 'Mandingos' as the principal slavers, and as members of a dangerous and hostile network. Even so, Burēma mobilised diplomatic contacts with the Mandinka rulers in regions in the north and north-west of Port Loko

\footnotetext{
194 Fyfe follows later British documentation that sees this ruler as a Muslim of Sarakole origins, see Fyfe, History, 6.

195 TNA, PRo, CO/267/45, MacCarthy to Bathurst (nº 37), 5 Aug. 1817, 2.
} 
through the ethnic argument, which made him an influential political player in the whole of the river region. ${ }^{196}$

Similar strategies of selectively using ethnic group identifications can be seen in some comparable biographies, notably in the case of the career of the 'Mandingo' Dala Modu Dumbuya in the first half of the nineteenth century. Although this leader never controlled the city of Port Loko, he remained an impressive figure in the immediate neighbourhood and major peace broker between different rulers and different ethnic groups at Magbele in 1836. As early as 1815, Dala Modu was playing the instruments of identity policy in the most ingenious ways: he even managed to procure for himself a leading position amongst the Baga populations of coastal Sierra Leone, although the latter were hostile to Islam. At the same time, 'the Almami' had secured the primary position among the many Muslim rulers of the Bullom Shore. ${ }^{197}$ Furthermore, he had already started to build up enormous prestige among Temne-speaking rulers, to become even greater over the next decades, as a reliable spokesman for the common interest.

While being less documented than the case of Dala Modu, the family of the Sanko in Port Loko is another example of such Dyula politics, although most of the information we have to hand is retrospective and slightly questionable. Some of the facts are nevertheless obvious. In 1816, various local families revolted against the rule of the Susu-speaking Sanko ruler, Brima Konkuri, and expelled his family from the town. The overthrow of the ruler did not initially mean the expulsion of all 'Susu': Port Loko, for some time, remained a 'mixed community'.198 However, in the long run, the politics of identification proved counter-productive. This began with diplomatic relations with the Europeans: in order to obtain the sympathies of the British in Freetown, the rebels emphasised their Temne-ness, claiming that they had just expelled a dynasty of 'strangers'.

In 1825, a British mission to Port Loko intervened in the succession of the city's ruler, the so-called 'Ali Karlie', Alkali Moriba Kindo Bangura. This British intrusion in local affairs was due in particular to worries about the trade routes, which, in this area, were already frequently interrupted by the wars between different Temne-speaking chiefs and other leaders, 'Mandinkas' or 'Susus'. The British governor, Charles Turner, did not have a deep understanding of any of

196 TNA, PRo, CO/267/29, Dawes, Observations on the Situation of Sierra Leone with respect to the surrounding Natives (without number), without date, 4-9.

197 TNA, PRo, CO/267/47, MacCarthy to Bathurst ( $\left.{ }^{\circ}{ }^{\circ} 56\right)$, 20 July $1818,3^{-4}$.

198 Howard, Allen M., 'Mande Identity Formation in the economic and political context of North-west Sierra Leone, 1750-190o', Paideuma 46, 2000, 13-35, 24-6; Wylie, Kingdoms, 37-41; Fyfe, History, 127. 
the group conflicts around the turban of the Alkali; he admitted to being not at all certain who amongst the contenders was a 'correct' candidate from an ethnic point of view. The fact that one contender for the throne had made himself a name as a protector of warrior bands that plundered 'the Fulas', regarded as the main slave merchants in the region, obviously was a point in his favour. Consequently, Turner's support guaranteed that Fatima Brima, the nephew of the late ruler, obtained the position: in this context, the British governor insisted that Brima had in any case been the true heir and favourite of a majority of Port Lokkans. ${ }^{199}$

In the immediate surroundings of Port Loko, Temne-speaking residents had quickly learned their lesson from this event. In Bara Loko, after the death of Pa Moriba, the representatives of the Bara and Sankong families obtained Turner's support as partners in keeping the trade roads open. They managed to present themselves as former victims of an invasion of Susu 'strangers.' ${ }^{200}$ During the 1840 succession of the Alkali of Port Loko, the Susu-speakers in the region were not able to interfere, although the announcements during the ceremonies were still made in Temne and Susu. ${ }^{201}$

As a whole, such manoeuvres were quite successful from the point of view of a section of the leading Temne-speaking families. Susu-speakers in the area lost their access to central power and the chance to make another claim for the position of Port Loko's ruler. The events of the 1810 s and 1820 s were locally interpreted as an ethnic takeover. They remained as such in the collective memories of the populations of the region, and, particularly of those who had lost out as a result of the settlement enforced by the British. This was confirmed during the invasion by the Lahai war bands in the 1850 - one or two generations after the political changes in Port Loko. The Susu-speaking warrior group of the Lahais occupied Kambia and wreaked havoc in many of the Temnespeaking communities of the Skarcies Rivers region, but they had another, more important, target. Numerous informants explained to the British commander that the Lahais wished, in particular, to take the town of Port Loko. ${ }^{202}$

\footnotetext{
199 TNA, PRO, CO/267/66, Turner to Bathurst (nº 91), 20 Dec. 1825, 3-9.

200 TNA, PRo, CO/267/66, Turner, Convention between His Excellency Major General Charles Turner B. Captain General and Governor in Chief of Sierra Leone and its Dependencies \&cc. $\& c$. and Caremo, Senior and Chief of the Barra Family, ... and Possessors of the Bacca Loco Territories (without number), 12 Dec. 1825, 2-3.

201 CMS, CA1/o 87/15, Reverend Nathaniel Denton, Journal extracts for the quarter ending Dec.r 25th 1840 (without number), without date, 2-3.

202 TNA, PRo, CO/267/260, Wise, British Commander at the Guinea Coast, to Grey, British admiral, Reporting operations conducted against the Sooso Chiefs...(without number), 5 Feb. 1858, 2-3, 7 .
} 
This was a risky operation, as the bases of the Susu army in the region of Kambia were on the whole not safe; but the campaign seemed necessary for 'historical reasons'. The informants claimed that the Lahai brothers, as Susu-speakers, considered the historical events in Port Loko as dishonouring their ethnic group, and wished to 'reconquer' the settlement to avenge the disaster of the 1820 s.

Missionary documentation from the Port Loko area, where the cMs became slowly re-entrenched after 1875 , points to growing polarisation of identifications in ethnic group terms as a direct consequence of the episode of the Lahai invasions. The rulers of Port Loko, Santigi Kondito and the Alkali, now began to identify more intensely as Temne. They thereby attempted to mobilise the different families in the region of the settlement to support more firmly the Alkali's power. ${ }^{203}$ In these discussions, the Temne-speaking adherents of the ruling family notably deplored the fact that Rogbon, a city in the surroundings of Port Loko, was still ruled by 'a Susu man'. 204

Religion did not help to overcome these differences. Strangers were often marked as 'Mandinka', and this in spite of the growing tendency in Port Loko towards Islamic conversion: no bridges were built between the different communities in Sierra Leone's north. The elites of Port Loko (and, indeed, the informants of the British residents) favoured defining non-Temne speakers as fundamentally different. ${ }^{205}$ In Port Loko, the dominant discourse of the $1880 \mathrm{~s}$ concentrated, however, on attempts to obtain British material support for local projects, including infrastructure and armament. In this context, the Alkali and leading chiefs were eager to present those projects as joint initiatives of various Temne communities, although neighbouring chiefs did not accept the claims of Port Loko's rulers. The strongest effect that this panTemne rhetoric had was on the British. Sometimes, the identification of the 'Temne' as one united group was quite negative: it led British Major Festing, passing through the town during travels, to remark that 'the Timinis are a

203 CMS, C Ar/o 29/4, John Alfred Alley, Journal (without number), without date [1879], 25; CMS, C A1/o 29/6, Alley, Journal October 1879 (without number), dated 1879.

204 CMs, C A1/o 29/4, Alley, Journal (without number), without date [1879], 23.

205 CMS, C A1/o 29/5, Alley, Journal From July to September 1879. J.A. Alley (without number), without date, 5 . Trusted Muslim advisors of the local rulers were exempted from this rhetoric, such as the 'Susu man' of Masimera, see CMs, C A1/o 29/8, Alley, Journal April June 30 th 1880 (without number), without date, 7. Others amongst the preachers came from regions far more to the north and northeast, i.e. the Fuuta Jallon or even Fuuta Tooro in Senegambia, see CMS, CA1/o 6o/55, Burtchaell to Rosler, Secretary of Church Missionary Society (without number), 22 Nov. 1878, 2. 
despicably dilatory lot, they want the white man to help them all they can and render none in return'. ${ }^{206}$

In the reality, there was still no permanent ethnic confrontation amongst local communities in the Port Loko area. As in the rest of the north of presentday Sierra Leone, this process of community-building was in decline after the creation of the Sierra Leone Protectorate in 1898 . With the end of the devastating regional warfare that had characterised the region in the second half of the nineteenth century, ethnic claims were no longer useful. During much of the first three decades of the twentieth century, in which the city became the centre of the paramount chieftaincy of Maforki, arguably the most important chiefdom of Sierra Leone's north, aggressive ethnic formulations were very much absent. ${ }^{207}$

At the end of the 1940s, Port Loko had grown into a fairly sizeable regional centre, and the local elite boasted the highest level of European-style education in all of the Northern Province. For decades, during the whole of the interwar period, the discourses on ethnicity had been dormant; in the end there was little to discuss. There were no open conflicts in the town's community, and no initiatives to highlight the settlement's Temne identity. ${ }^{208}$ It is, of course, difficult to assess the importance of ethnic sentiment in the everyday life of individuals, but it had no political role. In the course of the remobilisation in the north after the Second World War, these identifications reappeared on the stage with renewed importance.

In the context of Port Loko, this process was more strongly visible than in other parts of the north: the controversial memory of group hostilities defined through ethnic terms had remained alive, and it was now eagerly employed during the new conflicts. In the late 1940s, while the north seemed still generally calm and largely unaffected by ethnic hostilities, the Temne-speaking and

206 TNA, PRo, CO/879/29, African Confidential Print No. 366, Festing, Major A.M. Festing's Mission to Almamy Samodu - Diary (without number), without number, 7.

207 SLA, SPA 507/1, Death and Elections of Paramount Chiefs, Maforki Chiefdom, Acting Commissioner of the Northern Province at Makump, to Colonial Secretary at Freetown $\left(n^{\circ}\right.$ 66/10(4)), 5 Feb. 1923; SLA, SPA 507/1, Death and Elections of Paramount Chiefs, Maforki Chiefdom, Mac Robert, Commissioner of the Northern Province; Pa Kumrabai, Acting Chief, and others for the New Port Loko Section; Santigi Salifu of Bendugu and others for Sendugu Section; Alimami Suri of Kabata and others for Kabata Section; Alimami Konte and others for Romaka section; Alimami Suri of Karene and others for Rogberi Section; Alimami Kanu of Rotal and others for Malal Section; Santigi Tauya for Tauya Section, Agreement (without number), 5 April, 1949.

208 TNA, PRo, CO/1018/65, Cox, [Lord Hailey's Questionnaire:] Port Loko District, Present D. Bayley, District Commissioner, Port Loko (without number), 12 March 1948, 6. 
Susu-speaking communities of the Port Loko region demonstrated a longer memory. In that period, the Susu-speaking minority began to isolate itself entirely from the Temne-speakers, in a sort of non-violent but hostile separation. ${ }^{209}$

In 1955, violent conflict suddenly shook the Port Loko region. However, it antagonised, in the first instance, different groups of Temne-speakers. Alkali Modu III, the paramount chief of Maforki residing in the city, became the target of furious protests. Modu had installed a relatively 'authoritarian' regime that now, with moves toward political democratisation in the Protectorate, became more difficult to uphold. He had relied on forced labour to cultivate rice and maize on his own farms (he claimed that this was necessary to guarantee sufficient food stocks in the rural areas of Port Loko, but the British commissioners of inquiry would not believe him). Moreover, he demanded regular gifts from headmen of the surrounding villages, and would levy them if they refused to bring the respective goods. His right hand as messenger of the Native Authority, Sergeant Morlai, was infamous for his brutality towards any noncompliant headmen, and Modu III had also ordered corporal punishment for village leaders called to the Native Authority Court in Port Loko. ${ }^{210}$

These authoritarian practices had in themselves a certain ethnic note. While the paramount chief did not necessarily distinguish on group terms between individuals required for forced labour or headmen 'encouraged' to bring presents, he nonetheless treated Limba-speakers significantly worse than all the others. In court, Alkali Modu III was quite keen to imprison Limba-speaking debtors who, for 'being Limba', would remain in the barri until their debts were cleared, and who could obviously expect more frequently the recourse of the court to corporal punishment. ${ }^{211}$ However, these distinctions were not sufficient to turn the Limba-speakers against the Temne-speaking majority in the chiefdom. On the contrary, the short wave of riots in the 1950s was led by activists among the Temne-speaking headmen who were eager to finish with the Alkali's style of rule. ${ }^{212}$

209 TNA, PRo, CO/1018/65, Bailey, Details required by Lord Hailey. Port Loko District. Northern Province (without number), 5 Feb. 1948, 1.

210 TNA, PRo, CO/554/1993, Harold Willan, Commissioner of Inquiry, Report under Section 36 (2) Protectorate Ordinance (Cap. 185): Maforki Chiefdom - Alikali Modu III (without number), 7 Nov. 1956, 2, 6-7.

211 Ibid., 7.

212 SLA, Commission of Enquiry: Letters Submitted, Port Loko District, CE/P/77, Bowerson Decker to Chairman of Commission of Inquiry at Port-Loko (without number), 6 April 1956; SLA, Commission of Enquiry: Letters Submitted, Port Loko District, CE/P/77, 
As we have seen, Alkali Modu III belonged to the influential chiefly members of the SLPP, and his good contacts to Milton Margai gave him a certain degree of protection against the attacks of his adversaries. The members of the alliance of headmen, seasonal migrants, and young militants who protested against his exactions were particularly angered by these manoeuvres. Modu's removal came too late to calm their spirits. Furthermore, the machinations from Freetown to save the chief from removal only broadened the alliance in the region, and allowed for bridging the potential gap between Limba-speakers and Temne-speakers in the chiefdom, who thus found grounds for political cooperation. Only the Susu-speakers continued in opposition to the political majority in the district.

After the expulsion of the old chief, the overwhelming majority of Port Loko's political militants remained negative towards the dominance of 'southerners' in Freetown. In early 1961, the political activities of Siaka Stevens's All People's Congress, the new main opposition force on the scene in Sierra Leone, were warmly embraced by these militants who loudly demanded constitutional guarantees in order not to be marginalised in a future independent state. ${ }^{213}$

It can be said that Port Loko was indeed a microcosm that reflected very well the tendencies in Sierra Leone's Temne-speaking north. From the early conflicts between Temne and Susu that still had a very local perspective, to the second, more global wave of conflicts starting in the 1850 s, to a period of relative calm under colonial rule and the renaissance of the principle of ethnic mobilisation in the 1950s, the chronology is quite representative. In Port Loko, however, rather than its being a commercial centre that knew the passage of a relatively high number of 'foreigners', the conflicts between Temne-speakers and others were particularly bitter. They illustrate that, in the absence of other binding principles, the call to ethnic solidarity was always an option.

\section{Into the Bipolar Ethnic State: The All People's Congress and the Second Politicisation of Temne-ness}

The emergence of the All People's Congress in 1960 was, from the point of view of the colonial authorities and of the ministers of Sierra Leone's autonomous

Kumaka, Bollom, Kaffeh, to Chairman of Commission of Inquiry at Port-Loko (without number), 7 April 1956.

213 TNA, PRO, CO/554/2363, Resolutions passed at a Mass Meeting held at \{Port Loko\} on 17th February, 1961. (without number), 17 Feb. 1961. 
government, a serious problem - but, initially, not at all in the sense of an ethnicisation of political programmes in a country that was on the brink of national independence. For Milton Margai and his ministerial crew, the APC was dangerous because it appeared to forge a coalition of urban inhabitants, in the same way as the defunct UPP had attempted before, but without being too clearly a 'Creole party'. Also, the SLPP politicians were worried about their opponents' campaign against corruption. This touched upon Milton Margai's transactions, involving his own urban villa, with the Lebanese building company Milhem, and the obscure commercial activities of the ministers of finance and housing, Mohammad Sanusi Mustapha and Cyril Rogers-Wright. ${ }^{214}$ The British authorities remained relatively worried about this development, and their observations give us a picture that, while being distorted and Eurocentric, allows us nonetheless to follow step by step the APC strategies in the last months before Sierra Leone's independence. British officials regarded Stevens's party as, at the least, a movement 'inspired by Marxist propaganda', and they held that the APC received payments from Moscow and that Siaka Stevens had Soviet contacts organised via Ghana and Sékou Touré's 'Communist state' in Guinea-Conakry.215

Indeed, Stevens was able to mobilise a section of the urban electorate, and the victory of the APC in the November 1960 municipal elections in Freetown was celebrated as a paradigmatic surprise success. APC leaders claimed their electoral success was based on the support of very different 'tribes.'216 The party sought close collaboration with the leaders of the nascent Sierra Leonean

214 TNA, PRO, CO/554/2363, Telegram from Dorman to Macleod, British Secretary of State for the Colonies, Security Situation ( $\left.{ }^{\circ} 245\right), 24$ April 1961, 1.

215 TNA, PRO, CO/554/2363, Telegram from Dorman to Office of the British Prime Minister and Commonwealth Relations Office; Greenhill; King (without number), 26 April 1961, 1; TNA, PRo, CO/554/2363, Telegram from Dorman to Macleod ( $\left.{ }^{\circ} 79\right)$, 24 April 1961, 1; TNA, Pro, CO/554/2363, Telegram from Dorman to Macleod, Internal Security and Political Situation. (without number), 18 April 1961; TNA, PRO, CO/554/2363, Logan, British Embassy in Conakry, to Dorman ( ${ }^{\circ}$ 5), 17 April 1961, 1; TNA, PRO, FO/371/147540, British Embassy in Conakry, Guinea Affairs (without number), without date; TNA, PRO, $\mathrm{CO} / 554 / 2363$, Sierra Leone (without number), without date; MacDonald, Mairi, 'A vocation for independence: Guinean nationalism in the 1950s', in Tony Chafer and Alexander Keese (eds.), Francophone Africa at Fifty (Manchester: Manchester University Press, 2013), $30-43$.

216 TNA, PRO, CO/554/2363, Siaka Stevens for APC Working Committee, Sierra Leone's Forthcoming Independence - Points to Ponder: An Appraisal of the existing political situation in Sierra Leone, prepared by the All People's Congress of Sierra Leone (A.P.C.) (without number), 9 Feb. 1961, 6. 
trade unions, namely Marcus Grant and George Stone from the Sierra Leone Council of Labour, and gave itself the image of a social movement. In early 1961, Stevens and other APC leaders reacted with outrage to the refusal of the Margai government to hold new elections before independence and called for social protests. Stevens and another two dozen APC politicians even ended up in prison for some time. ${ }^{217}$

However, even with its social rhetoric, the APC was equally successful in the Temne-speaking regions of Sierra Leone's north, and it also won the vote of the Limba-speakers of the same region. British observers were perplexed about Stevens's success. In their view, Stevens was, like the SLPP leaders, a typical 'urban' politician and very similar to Margai. ${ }^{218}$ They were therefore quite surprised at the landslide mobilisation which the APC was able to achieve in the areas of Port Loko and Kambia, and also in mainly Temne-speaking Marampa, where the opposition party made visible inroads from $1960 .{ }^{219}$

The developments of the 1950 s had not been forgotten. The impression that 'southern' or 'Mende' politicians had attempted to change the distribution of resources in the territory, was long-lasting. According to inquiries by British administrators who wished to guarantee a smooth transfer of power in the territory, the distrust of Temne-speakers towards Mende domination in the Freetown autonomous government had even grown. The behaviour of local leaders reflected these impressions: in the northern centres of Magburaka, Makeni, Kambia, and Port Loko, Temne-speaking adherents were assembled to loudly demand constitutional changes and elections before independence. Although these assemblies had no immediate effect - both the SLPP government and the British authorities were determined to proceed with the process leading to independence - their impact was strong in directing the formerly diffuse grudges of local Temne-speakers towards a clearer political programme. ${ }^{220}$ Even

217 TNA, PRO, CO/554/2363, Telegram from Dorman to Macleod $\left(\mathrm{n}^{\circ} 71\right), 15$ April 1961, 1; TNA, PRo, CO/554/2363, E.C. Burr, Principal of International Relations Department, Colonial Office, to Aaron Emanuel, Assistant Secretary, West African Department of the C.O. (without number), 3 March 1961; TNA, PRo, CO/554/2363, Telegram from Dorman to Macleod, Security Situation ( $\mathrm{n}^{\circ}$ 245), 24 April 1961, 1; TNA, PRO, CO/554/2363, Telegram from Dorman to Macleod (without number), 18 April 1961, 1.

218 TNA, PRo, CO/554/2363, [Revision of Draft to Mr. Tilney] (without number), 7 March $1961,2$.

219 TNA, PRo, CO/554/2363, Sierra Leone Intelligence Committee, All People's Congress (A.P.C.): Appendix 'A' to S.L.I.C. Report for September, 1960 (without number), without date, 2.

220 See, particularly, TNA, PRO, CO/554/2363, Resolution of Participants of Public Meeting in Kenema [Bombali District] (without number), 17 Feb. 1961, 2; TNA, PRO, CO/554/2363, Resolutions passed at a Mass Meeting held at \{Port Loko\} on 17th February, 1961. (without 
more, this mobilisation spilled back into the urban agglomeration of Freetown, where it further strengthened the APC support base. The 'Temne Hungry Unions' of Temne-speaking unemployed in the urban area became a very vocal instrument of Siaka Stevens's attempts at mobilisation. ${ }^{221}$

In 1961, this renaissance of Temne ethnic mobilisation was still insufficient to bring the APC into power. The unequivocal support of the British government for the Margai administration, and the years-long control of SLPP ministers over the levers of power, would not disappear overnight. However, the foundations were laid. During the 196os, the combination of a party politics that relied on cooperation with paramount chiefs, and the evolution of a bipolar ethnic constituency, perpetuated itself. The memory of the late 1950s, which led Temnespeakers of the north to regard the SLPP elite as southern, corrupt, and hostile, remained vivid, and would have consequences for the post-colonial state.

After 1969, the APC would repay in kind. ${ }^{222}$ Relying on a Creole-Temne/ Loko/Limba alliance, and winning the votes of discontented populations from other parts of the new state, Siaka Stevens became the new ruler of Sierra Leone. Instead of attempting to end the ethnic polarisation that had (re-) emerged in the 1950s, the new government perpetuated the confrontation by installing a cabinet and a senior administration dominated by Temne-speakers and Loko-speakers. Moreover, in the Mende-speaking regions, they replaced paramount chiefs with their own clients, paving the way for a new wave of discontent. ${ }^{223}$ With this platform of ethnic mobilisation, the Stevens government repeated a pattern that had started as forms of ethnic mobilisation over the nineteenth century, and had only been interrupted by relative stabilisation of regional resource distribution by the colonial state.

number), 17 Feb. 1961; TNA, PRo, CO/554/2363, 'Makeni District Community' to District Commissioner of Makeni, Resolutions passed by the Bombali District Community at a mass meeting held at Makeni on the 17th February, 1961. (without number), without date, 1; TNA, PRo, CO/554/2363, 'Tonkolili District Community' to District Commissioner of Magburaka, Resolutions passed by the Tonkolili District Community at a mass meeting held at Magburaka on the 17th February, 1961. (without number), 17 Feb. 1961. TNA, PRo, CO/554/2363, Sierra Leone Intelligence Committee, All People's Congress (A.P.C.): Appendix 'A' to S.L.I.C. Report for September, 1960 (without number), without date, 3.

222 Zack-Williams, Alfred B., 'The Ekutay: Ethnic Cabal and Politics in Sierra Leone', in E. Ike Udogu, The Issue of Political Ethnicity in Africa (Aldershot etc.: Ashgate, 2001), 125-47, 130-3.

223 Fanthorpe, Richard, 'On the Limits of Liberal Peace:Chiefs and Democratic Decentralization in Post-War Sierra Leone', African Affairs 105(418), 2005, 27-49, 42. 